University at Buffalo School of Law

Digital Commons @ University at Buffalo School of Law

5-16-2008

\title{
Creating a Public Plan for New York's Great Lakes Offshore Wind Power: A Strategy for Energy and Economic Development
}

Dwight E. Kanyuck

Robert S. Berger

University at Buffalo School of Law, berger@buffalo.edu

Follow this and additional works at: https://digitalcommons.law.buffalo.edu/other_scholarship

Part of the Energy and Utilities Law Commons, and the Natural Resources Law Commons

\section{Recommended Citation}

Dwight E. Kanyuck \& Robert S. Berger, Creating a Public Plan for New York's Great Lakes Offshore Wind Power: A Strategy for Energy and Economic Development, (2008).

Available at: https://digitalcommons.law.buffalo.edu/other_scholarship/40

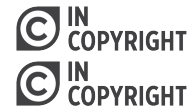

This Article is brought to you for free and open access by the Faculty Scholarship at Digital Commons @ University at Buffalo School of Law. It has been accepted for inclusion in Other Scholarship by an authorized administrator of Digital Commons @ University at Buffalo School of Law. For more information, please contact lawscholar@buffalo.edu. 


\section{Creating a Public Plan for New York's Great Lakes Offshore Wind Power}

\section{A Strategy for Energy and Economic Development}

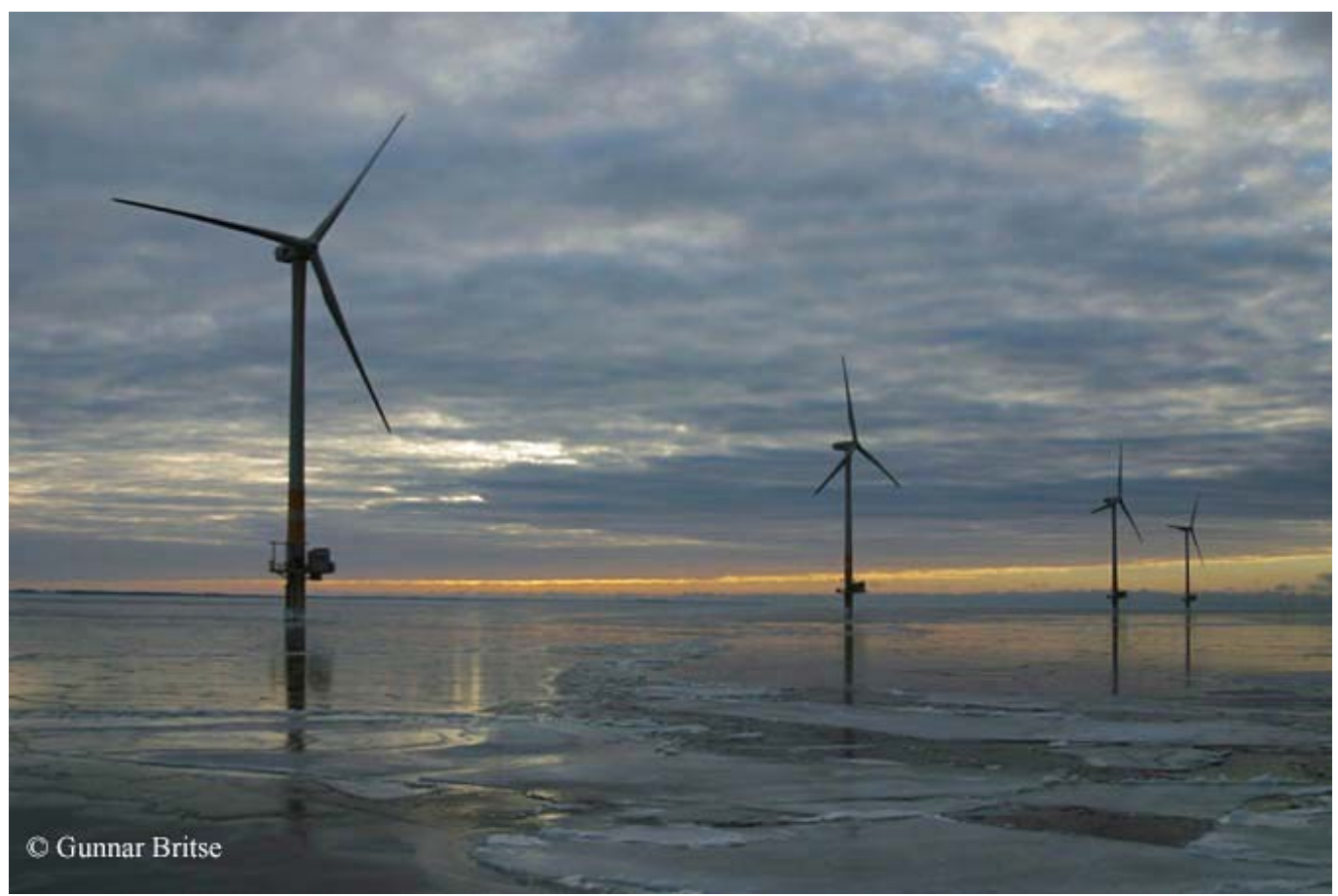

Prepared by the

University at Buffalo Law School

Environment and Development Clinic

for the

Wind Action Group

May 2008

T2 University at Buffalo Law School

The State University of New York

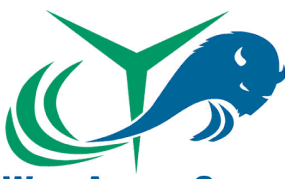




\title{
Creating a Public Plan for New York's Great Lakes Offshore Wind Power
}

\section{A Strategy for Energy and Economic Development}

\author{
Prepared by the \\ Environment and Development Clinic \\ University at Buffalo Law School \\ Robert S. Berger, Director \\ Dwight Kanyuck \\ for the \\ Wind Action Group \\ Robert Knoer, Chair
}

May 2008 


\section{Report prepared by}

\section{Environment and Development Clinic University at Buffalo Law School \\ The State University of New York \\ 507 O’Brian Hall \\ Buffalo, NY 14260-1100 \\ T: 716.645 .2167 \\ F: 716.645.2064 \\ W: www.law.buffalo.edu/Clinics}

Report prepared for

Wind Action Group

E: windmail@GREENGOLD.org

W: www.greengold.org/wind/

\section{Acknowledgements}

Special thanks to Laura Mangan for her help producing this report and to Gunnar Britse for allowing the use of his photographs. 
Acronym and Abbreviation List ............................................................ ii

Executive Summary ........................................................................... iii

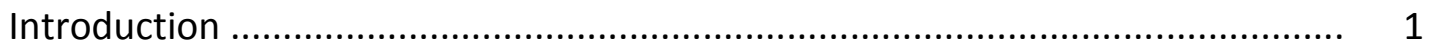

A. Benefits of Offshore Wind Energy Development in

New York's Great Lakes ........................................................................... 2

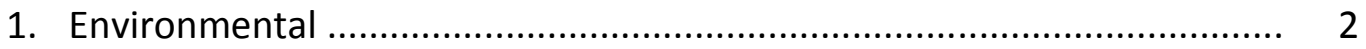

2. NYGLOW as an Economic Development Engine ................................ 3

a. Quebec .......................................................................................... 4

B. Offshore Wind Development in North America ..................................... 7

1. New Jersey ..................................................................................... 7

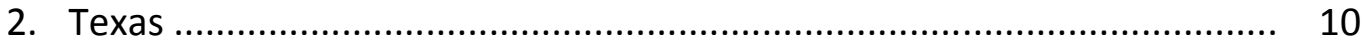

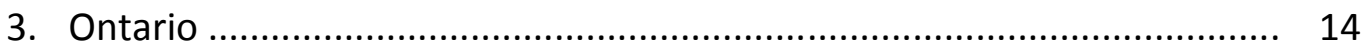

4. Cape Wind …................................................................................. 17

5. New York-Long Island ..................................................................... 19

C. Financial Incentives for Offshore Wind ............................................... 21

1. U.S. Wind Energy Incentives .......................................................... 22

2. European Offshore Wind Incentives .................................................... 24

3. RGGI and Offshore Wind Incentives in New York ................................ 26

D. A Strategy for NYGLOW ..................................................................... 27

1. Who Should Implement the Process: NYPA and NYSERDA have the Power ................................................ 29

2. The Process for Developing the NYGLOW Strategy ........................... 32

3. Implementing NYGLOW ................................................................... 34

4. Policy Recommendations .......................................................... 36

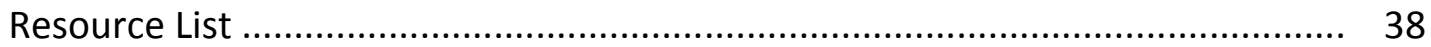




\section{Acronym and Abbreviation List}

\begin{tabular}{|c|c|}
\hline$€ / k w-h r$ & Euros per Kilowatt Hour \\
\hline CREBs & Clean Renewable Energy Bonds \\
\hline $\mathrm{CO2}$ & Carbon Dioxide \\
\hline DEIS & Draft Environmental Impact Statement \\
\hline ESDC & Empire State Development Corporation \\
\hline FPL & Florida Power and Light \\
\hline GEIS & Generic Environmental Impact Statement \\
\hline GHG & Greenhouse Gas \\
\hline GLO & Texas General Land Office \\
\hline IDA & Industrial Development Authority \\
\hline IPSP & Ontario Power Authority Integrated Power System Plan \\
\hline LIOWP & Long Island Offshore Wind Park \\
\hline LIPA & Long Island Power Authority \\
\hline MEPA & Massachusetts Environmental Policy Act \\
\hline MMS & United States Mineral Management Service \\
\hline MNR & Province of Ontario Ministry of Natural Resources \\
\hline MW & Megawatt \\
\hline NEPA & National Environmental Policy Act \\
\hline NJCEP & New Jersey Clean Energy Program \\
\hline NJEDA & New Jersey Economic Development Authority \\
\hline NYGLOW & New York's Great Lakes Offshore Wind \\
\hline NYPA & New York Power Authority \\
\hline NYSERDA & New York State Energy Research and Development Authority \\
\hline OGS & New York State Office of General Services \\
\hline PEIS & Programmatic Environmental Impact Statement \\
\hline PTC & Production Tax Credit \\
\hline REPI & Renewable Energy Production Incentive \\
\hline RES & Ontario Power Authority Renewable Energy Supply \\
\hline RFP & Request for Proposals \\
\hline RGGI & Regional Greenhouse Gas Initiative \\
\hline RPS & Renewable Portfolio Standard \\
\hline SEQR & New York State Environmental Quality Review \\
\hline U.K. & United Kingdom \\
\hline U.S. & United States \\
\hline WNY & Western New York \\
\hline
\end{tabular}




\section{EXECUTIVE SUMmARY}

\section{Introduction}

The first report of (then) Lt. Governor Patterson's Renewable Energy Task Force includes a recommendation to "explore the possibilities" of development of offshore wind energy resources (Offshore Wind) in New York's Great Lakes as part of a strategy of "reducing dependence on fossil fuels, stimulating investment in clean energy alternatives, and mov[ing] to a clean energy economy in New York State." As it had in the $19^{\text {th }}$ century with the advent of hydropower on the Niagara River, Western New York's (WNY's) proximity to the Great Lakes provides an opportunity to again become a leader in the generation of clean renewable energy as an engine for regional economic development and to leverage the region's technology and manufacturing infrastructure to further an economic renaissance centered around alternative energy and a reputation as a clean livable community. By utilizing the resources of NYPA and NYSERDA, in conjunction with the Upstate ESDC, New York can move forward with a strategy to develop New York's Great Lakes Offshore Wind (NYGLOW) in a way that gains the support of the local community and spurs the development of an Offshore Wind industry in Western New York.

This report is the final product of a project evaluating the legal and policy considerations for the development of NYGLOW consistent with the Wind Action Group's mission to develop information to allow thoughtful, informed decisions on the future of wind power in WNY and to advocate for and promote ways to develop WNY's wind resource in a way that maximizes the benefits to the public. ${ }^{1}$ The need for a full discussion of these issues is particularly important because wind turbines would be placed in bodies of fresh water that are the source of drinking water for millions of people. The potential economic development, environmental, and energy benefits of NYGLOW are discussed and a strategy for siting, environmental review, and incentives to gain public acceptance and attract significant investment in NYGLOW is recommended, drawing on other approaches used for developing Offshore Wind elsewhere in North America.

\section{Benefits of NYGLOW}

Lakes Erie and Ontario have the potential to provide a significant source of clean renewable energy to WNY. While further study is needed to determine the prudent quantity of the developable Offshore Wind resource, development of just $10 \%$ of the theoretical Offshore Wind resource (about 8,200 megawatts (MW)) would be equivalent

\footnotetext{
${ }^{1}$ For more about the Wind Action Group, go to http://www.greengold.org/wind/. For the full text of the reports go to http://www.greengold.org/wind/legal.php.
} 
to adding the renewable energy capacity of more than three power plants the size of the Robert Moses Niagara Hydroelectric Plant. This level of development would significantly offset the greenhouse gas, sulfur dioxide, nitrogen oxide, and mercury emissions associated with coal power generation and provide a stably priced supply of energy for years to come.

Furthermore, by committing to develop this resource in a prudent manner, WNY will create a demand for wind energy materials and services that, when leveraged with its existing manufacturing and technology infrastructure, will enable WNY to become a worldwide leader in Offshore Wind technology and component manufacturing. The Province of Quebec has effectively utilized a similar strategy by linking access to a significant (4,000 MW) land-based wind energy market to local economic development and local content requirements to provide a market attractive to developers, but in a way that spurs investment in converting some of Quebec's existing manufacturing infrastructure to wind energy component manufacturing. Quebec's current wind energy offerings are expected to result in over $\$ 4$ billion in investment, $60 \%$ to be expended in Quebec, and result in 1,500 full time jobs-and significant additional offerings are planned for the future.

\section{Approaches to Offshore Wind Development}

While NYGLOW, and U.S. Offshore Wind generally, have tremendous potential as an energy source, the technology is less developed than on-land wind energy technology at this time and needs to overcome short-term cost, siting, and technology hurdles. There are currently no Offshore Wind facilities in operation in the U.S, but there are about 1,000 MW of Offshore Wind facilities in operation in Europe and an additional 9,000 MW approved through 2011-indicating that with proper siting processes and development incentives, Offshore Wind is commercially feasible and New York should be planning for it. To date, New Jersey, Texas and Ontario are encouraging Offshore Wind through various means that have application to a strategy for NYGLOW.

New Jersey's approach has combined state-funded environmental review, intended to comprehensively understand the potential environmental, aesthetic, and economic impacts of Offshore Wind in the New Jersey coastal regions, with a \$19 million financial incentive to encourage the development of a $350 \mathrm{MW}$, privately funded pilot facility that will enable the state to fully assess environmental, economic, and energy transmission considerations associated with Offshore Wind. Texas and Ontario have amplified their unique jurisdictional and government organizational structures, which are also present in New York, to streamline the siting and development processes. Ontario and Texas, like New York, have control over the granting of property rights to the underwater lands targeted for Offshore Wind development-an advantage generally not available to states on the east coast of the U.S. where the federal government has jurisdiction over underwater lands. Texas and Ontario also offer the benefit of one central agency with one power procurement process for developers to 
deal with--while maintaining full environmental review processes. NYPA has the potential to provide this role as it has extensive powers as a state authority over land acquisition and the ability to enter into power purchase contracts.

\section{A Strategy for NYGLOW}

NYPA and NYSERDA collectively have the statutory authority, and mission, to initiate and implement the comprehensive strategy of NYGLOW. NYSERDA, as New York's lead agency for the development of safe, dependable, renewable, and economic energy resources, is currently conducting feasibility studies for Offshore Wind and has the financial resources and authority to establish a framework for environmental review and siting processes for NYGLOW. NYPA, which maintains a policy of cooperating with NYSERDA to implement new energy technologies, has long had a role in the development of clean, renewable energy in New York. It has the financial resources, land acquisition powers, and economic development mission necessary to fully implement NYGLOW.

As is being done in New Jersey, it is first necessary to understand the potential environmental, aesthetic, and economic impacts of NYGLOW, as well as the energy development potential, in a way that provides a forum for public participation. The federal Programmatic Environmental Impact Statement (PEIS) or New York's Generic Environmental Impact Statement (GEIS) processes can provide the framework for this analysis and discussion in conjunction with appropriate state-funded environmental and energy studies. Execution of this process is clearly within NYSERDA's mission and could be funded through income obtained from the auctioning of carbon emission allowances from the Regional Greenhouse Gas Initiative (RGGI). One outcome of these studies could be, as recommended in New Jersey, the initiation of a commercial scale Offshore Wind pilot facility.

Finally, as the potential opportunity associated with NYGLOW crystallizes, NYPA should lead its implementation. A streamlined procurement process, maintaining strict environmental review and public participation requirements developed through the PEIS or GEIS processes, should be developed to enable the creation of a substantial market for NYGLOW, and the accompanying demand for construction services and component manufacturing. NYPA could be the exclusive developer of the projects or support private development projects. In either case, bid criteria could include local content requirements to spark regional economic development, and additional incentives could be provided through the Upstate ESDC to convert existing or create new manufacturing facilities and centers for technology development to foster an Offshore Wind industry in Western New York. 


\section{Summary of Policy Recommendations}

1. A PEIS or GEIS process should be initiated by NYSERDA, in cooperation with the Army Corps of Engineers, to assess the potential environmental, aesthetic, economic development, and energy development impacts of NYGLOW in a way that invites public participation.

2. NYSERDA should initiate and fund, through funds acquired through RGGI emissions allowance auctions, comprehensive environmental and energy studies necessary to support the PEIS or GEIS processes.

3. NYSERDA and NYPA should evaluate the need for a commercial scale NYGLOW pilot facility to fully assess the environmental and energy integration impacts as well as financial viability of NYGLOW.

4. NYPA should lead the necessary procurement and environmental review processes, consistent with the findings of the GEIS or PEIS and the pilot facility, to enable a large-scale rollout of the NYGLOW program. NYPA should work with Upstate ESDC and local county IDAs to provide economic development incentives for establishing an Offshore Wind manufacturing and technology industry in Western New York.

5. The Wind Action Group should engage all elements of the community in a discussion of this topic and help organize an advocacy campaign to implement the NYGLOW strategy. 


\title{
Creating a Public Plan for New York's Great Lakes Offshore Wind Power
}

\author{
A Strategy for Energy and Economic Development
}

\section{Introduction}

The first report of then Lieutenant Governor Patterson's Renewable Energy Task Force, offering a roadmap for "reducing dependence on fossil fuels, stimulating investment in clean energy alternatives, and mov[ing] to a Clean Energy Economy [] in New York State," ${ }^{2}$ encourages the development of offshore wind resources in New York's Great Lakes to explore the possibilities for a significant source of clean renewable energy. ${ }^{3}$ As in the late $19^{\text {th }}$ century with the advent of hydropower on the Niagara River, Western New York's proximity to the Great Lakes provides an opportunity to again become a leader in the generation of clean, renewable energy and to use that clean energy as an engine for regional economic development. By leading the development of offshore wind power generation (Offshore Wind) in North America, Western New York can provide a significant, indefinite supply of stably priced clean energy to the region. In so doing, Western New York can leverage the region's technology and manufacturing infrastructure to attract Offshore Wind developers and manufacturers, furthering an economic renaissance centered around alternative energy and a reputation as a clean, livable community.

This report is the final product of a project evaluating the legal and policy considerations for the development of New York's Great Lakes Offshore Wind (NYGLOW) consistent with the Wind Action Group's mission to develop information to allow thoughtful, informed decisions on the future of wind power in Western New York (WNY) and to advocate for and promote ways to develop WNY's wind resource in a way that maximizes the benefits to the public. ${ }^{4}$ Previous background reports have focused on the policies to support the creation of Offshore Wind manufacturing jobs in WNY ${ }^{5}$ and strategies for public acceptance, project siting, and environmental review. ${ }^{6}$ This report recommends a strategy for moving forward with NYGLOW in a way that gains the support of the local community and spurs the development of an Offshore Wind industry in Western New York. Initially, this report provides an overview of the

\footnotetext{
${ }^{2}$ New York Lieutenant Governor's Renewable Energy TASk Force, Clean, SeCure Energy and Economic Growth: A COMMITMENT TO RENEWABLE ENERGy ANd INCREASEd ENERgy INDEPENDENCE, The Challenge (February 2008) available at http://www.ny.gov/governor/press/lt RETF Report.pdf.

${ }^{3}$ Id. at 10.

${ }^{4}$ For more about the Wind Action Group, go to http://www.greengold.org/wind/.

${ }^{5}$ Robert SHAW, Wind Action GROUP, OfFSHORE WIND'S ROLE IN DEVELOPING A WIND ENERGY INDUSTRY IN WESTERN NEW YORK, (May 2007), http://greengold.org/wind/legal.php.

${ }^{6}$ DWight Kanyuck, Wind Action Group, Promoting Offshore Wind Energy in NeW York's Great Lakes, (May 2007), http://greengold.org/wind/legal.php.
} 
potential benefits, both environmental and economic, of NYGLOW. This discussion is followed by an evaluation of other Offshore Wind development efforts in North America, financial incentive programs in the U.S. and Europe, and their potential application for a strategy for Western New York. Finally, this report discusses and recommends leveraging the resources of the New York Power Authority (NYPA) and New York State Energy Research and Development Authority (NYSERDA), in conjunction with the Upstate Empire State Development Corporation (Upstate ESDC), to establish a siting and environmental review process that gains public support and provides the necessary incentives to attract significant investment in NYGLOW.

\section{A. The Benefits of NYGLOW}

\section{Environmental Benefits}

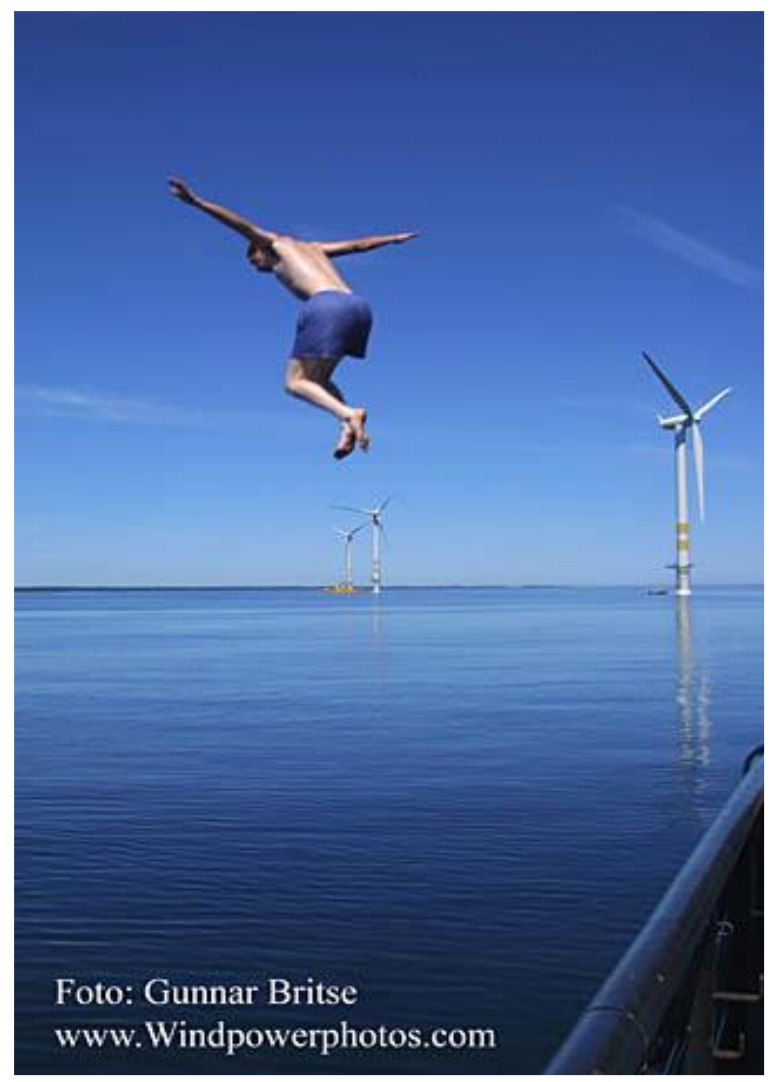

Andrew Takes a Bath, Ytrre Stengrund, Sweden

The offshore wind resource available in New York's Great Lakes can provide a significant source of clean renewable energy to Western New York. The theoretical potential power output obtainable from offshore Great Lakes wind turbines, using current technology, has been estimated at more than 249 gigawatts of power generating capacity, ${ }^{7}$ including about 14 gigawatts for Lake Ontario and 68 gigawatts for Lake Erie. ${ }^{8}$ This power generation potential represents more than the current electrical energy production of the Great Lakes coastal regions in the United States and Canada combined and benefits from proximity to major metropolitan load centers. ${ }^{9}$ While further analysis of technical, environmental, and economic considerations is necessary to determine the prudent quantity of this theoretical wind resource that should be developed, developing only $10 \%$ (about 8.2 gigawatts or 8,200 megawatts (MW)) of this resource would be equivalent to adding the renewable generating capacity of more than three power plants the size of the Robert

\footnotetext{
${ }^{7}$ See generally David Bradley, A Great Potential: The Great lakes as a Regional Renewable Energy Source, 2831 (February 6, 2004), http://greengold.org/wind/documents/107.pdf.

8 Id. at 29.

${ }^{9}$ Id. at 5.
} 
Moses Niagara hydroelectric plant. ${ }^{10}$ Alternatively, this level of development could offset the greenhouse gas, sulfur dioxide, and mercury emissions of about fourteen coal fired power plants the size of the Dunkirk Generating Station. ${ }^{11}$

Of course, there are potential environmental concerns with Offshore Wind as well, especially because these turbines would be placed in bodies of fresh water that are the source of drinking water for millions of people. The Great Lakes Fishery Commission has expressed concern about the effect of lakebed alterations from wind energy projects on aquatic habitat in the Great Lakes. ${ }^{12}$ As discussed in one of the background papers for this project, all of the relevant Great Lakes binational commissions and environmental advocacy groups must be fully engaged in this process. ${ }^{13}$

\section{NYGLOW as an Economic Development Engine}

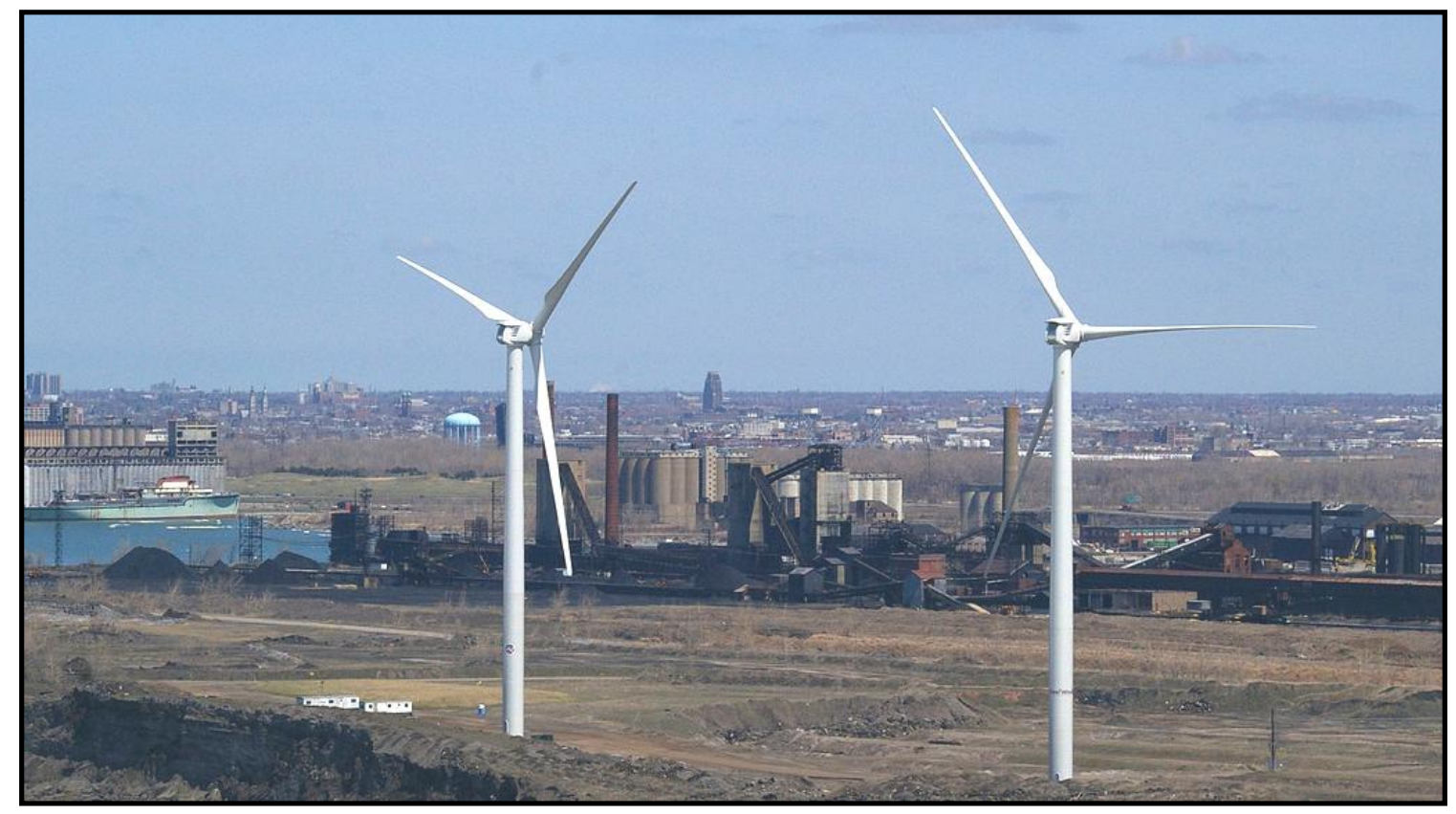

Steel Winds Urban Wind Farm, Buffalo, New York

By committing to develop this resource in a prudent manner, New York will also put into motion a significant economic development engine, not only from another stably priced source of clean, renewable energy, but from the demand created for wind

\footnotetext{
${ }^{10}$ Energy Information Administration, Existing Electric Generating Units in the United States, 2005 (April 17, 2008) available at http://www.eia.doe.gov/cneaf/electricity/epa/epat2p2.html. The Robert Moses Niagara hydroelectric plant has a nameplate generating capacity of about 2,429 MW.

${ }^{11}$ Id. The Dunkirk Generation Station has a nameplate generating capacity of 592 megawatts.

${ }^{12}$ DaVid Dempsey et Al, Conserving Great lakes Aquatic Habitat from Lakebed Alteration Proposals, Great LAKES FISHERY COMMISSION, (February 2006), available at http://www.glfc.org/research/reports/Dempsey.pdf.

${ }^{13}$ Kanyuck supra note 5 at 5-7.
} 
energy materials and services. ${ }^{14}$ With existing manufacturing capacity, the supply of offshore wind turbines is not expected to meet the anticipated near future demand. " $[A] n$ increase in North America's offshore turbine manufacturing footprint is crucial for the [Offshore Wind] market [in North America to develop and] . . c currently, it would be easier for a European manufacturer to build a new plant in the U.S. or Canada than in Europe."15 Western New York could initially attract Offshore Wind project developers, and their attendant demand for project management, construction and maintenance services, because of its proximity to the abundant offshore wind resource. With the region's existing infrastructure in manufacturing and technology, coupled with appropriate incentives, Western New York could then become a worldwide leader in Offshore Wind technology and component manufacturing. A recent analysis estimated that extending the federal support for renewable energy for ten years could increase the domestic share of manufactured wind equipment from $30 \%$ to $70 \%$. ${ }^{16}$ Another study of potential new job generation created from wind energy investment indicates that an investment of $\$ 1$ billion in wind energy projects, such as Offshore Wind, would be sufficient to support about 3,000 manufacturing jobs in wind energy materials and components. $^{17}$

\section{a. Quebec}

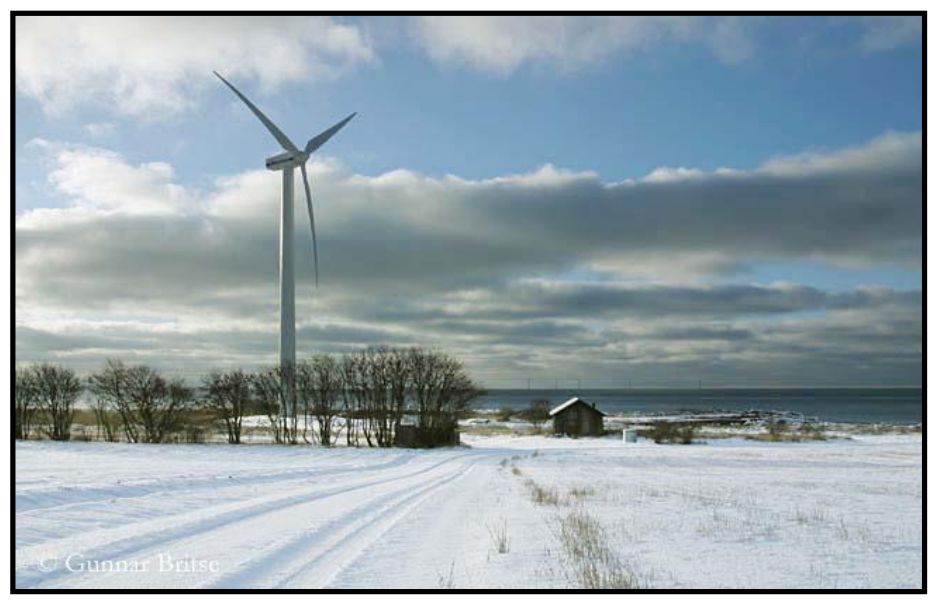

Winter 2002 Näsudden, Gotland

(C) Gunnar Britse, www.windpowerphotos.com
The Province of Quebec offers an example of successful use of a wind energy development program to drive economic development.

The energy strategy of the Government of Quebec calls for creating a significant wind energy resource to complement an expanding hydroelectric power supply base. ${ }^{18}$ This strategy provides

\footnotetext{
${ }^{14}$ Shaw supra note 4 at 2-3.

15 Jennifer Delony, Windbearings, North American Windpower, March 2008 at 4 (quoting John Koustoff, CEO of Trillium Power Wind Corp).

${ }^{16}$ Congressional Research Service Report, Renewable Energy: Background ANd ISSUeS for the $110^{\text {Th }}$ Congress, 113 (Dec. 2007) (quoting testimony of Ryan Wiser of Lawrence Berkeley National Laboratory).

${ }^{17}$ George Sterzinger and Matt SVRCEK, Wind Turbine DeVelopment: Location of Manufacturing Activity, Renewable Energy Policy Project (September 2004) available at http://www.repp.org/articles/static/1/binaries/WindLocator.pdf.

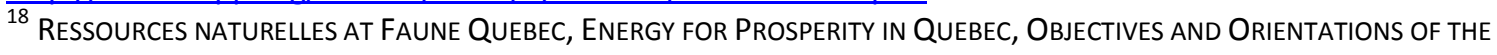
ENERGY STRATEGY, 14-15 (November 2005) available at http://www.mrnf.gouv.qc.ca/english/publications/energy/strategy/guidelines-strategy.pdf.
} 
for the "optimal development of wind energy to supply Quebec's power grid," which was determined to be an installed total of $4,000 \mathrm{MW}$ of wind energy capacity by $2015 .{ }^{19}$ A key aspect of Quebec's strategy is the use of its hydropower reservoirs to modulate hydropower generation to compensate for wind resource availability. ${ }^{20}$ Similarly, Western New York has existing hydropower reservoirs with modulating capability to use hydropower to optimize wind energy power generation at the Lewiston PumpGenerating Plant that is part of the NYPA Niagara Power Project. ${ }^{21}$

Contrary to the typical approach used in the United States, which generally bids one project at a time, the Province instructed Hydro-Quebec to bid the target wind power in large packages to create a "gold-rush fervour among potential suppliers." ${ }^{22}$ In response to its first call for tenders in 2003, Hydro-Quebec awarded 1,000 megawatts of contracts to purchase wind power. ${ }^{23}$ Subsequently, Hydro-Quebec issued a second call for tenders in 2005 for 2,000 MW of wind power due in September 2007. ${ }^{24}$ HydroQuebec's criteria for the evaluation of bids went beyond price per kilowatt-hour, also considering economic development, social, and environmental factors. ${ }^{25}$ These included: "the maximization of economic spin-off benefits for Québec and its regions (reflected in compulsory Québec and regional content in each bid, and a competitive price for the purchase of electricity); the economic development of local and aboriginal communities; and the development, within Québec, of a wind turbine manufacturing industry with a high technology content . . ." ${ }^{26}$ (a minimum of 30 percent of the wind turbine cost is to be expended in the Mantane or Gaspe region of Quebec and at least 60 percent of the total wind farms costs are to be incurred in Quebec). ${ }^{27}$ The remaining $500 \mathrm{MW}$ of capacity will be targeted specifically to small projects and will focus on First Nations and regional municipalities. ${ }^{28}$

Because of the "chance at the bonanza" associated with the large offering, ${ }^{29}$ the response to the calls for tenders was strong, despite the challenge of meeting the local

\footnotetext{
${ }^{19}$ Id. at 15.

${ }^{20}$ Id. A key advantage of the Quebec scheme is that hydropower represents $96 \%$ of Quebec's power generation capacity. Id. at 14.

${ }^{21}$ Niagara Power Project, New York Power Authority, http://www.nypa.gov/facilities/niagara.htm (last visited December 1, 2007).

${ }^{22}$ Lynn Moore, Who Will Reap the Wind?, The Gazette (Montreal), (September 8, 2007) available at http://www.canada.com/montrealgazette/news/business/story.html?id=eacffe52-2edb-4bc2-a53522c1bdfa1b06.

${ }^{23}$ Ressources naturelles at Faune Quebec, Wind energy projects in Quebec, http://www.mrnf.gouv.qc.ca/english/energy/wind/wind-projects.jsp, (last visited November 25, 2007). 24 Id.

25 Id.

${ }^{26} / d$.

${ }^{27}$ Lynn Moore, Developers stake wind claims, The Gazette (Montreal), (September 20, 2007) available at http://www.canada.com/montrealgazette/news/business/story.html?id=a1517cca-474f-4a83-9d899c07379be3a7.

${ }^{28}$ Wind energy projects in Quebec supra note 22

${ }^{29}$ Who Will Reap the Wind supra note 21.
} 
content requirements, and demonstrated that wind energy "potential can be harnessed at very competitive rates." 30 The tender offer for 2,000 MW attracted bids from 25 developers for 66 projects utilizing five different turbine manufacturers with a total capacity of 7,722 MW. ${ }^{31}$ The winning bids were awarded in May 2008, had an average electricity price of $\$ 0.105 / \mathrm{kw}$-hr and will result in a capital investment of $\$ 5.5$ billion. ${ }^{32}$ As required by the bid evaluation criteria for the call for tenders, the winning bids met the local content criteria described above. ${ }^{33}$

Because of the large potential resource of offshore wind in New York's Great Lakes (8,200 MW if $10 \%$ of the theoretical resource were developed, see infra page 2), New York State could use a Quebec-like strategy to attract economic development to Western New York. (As discussed in one of the background papers, the local content requirement raises possible Commerce Clause issues in the U.S., ${ }^{34}$ but we suggest an analysis and strategy that should overcome any problems in Section D, infra.) Quebec's 2,000 MW call for tenders alone was expected to result in \$4 billion in wind energy investments, 60 percent to be expended in Quebec, and create 1,500 full time jobs, including local turbine manufacturing. ${ }^{35}$ A similar approach to NYGLOW would not only attract large-scale interest and investment to the region, but could cause Offshore Wind to become a core industry, supplying both the Canadian and U.S. Great Lakes with Offshore Wind technologies.

Recognizing the potential environmental and economic benefits of Offshore Wind, it is crucial that a process be followed that considers the above benefits, yet fully evaluates all of the possible concerns and problems as well. What is the proper mechanism to obtain input from all stakeholders and create a plan that gains the acceptance of the community? How would a prudent level of development be determined that properly balances environmental, economic, and energy generation issues, and what governmental action and leadership is necessary? The background papers for this project discuss many of these issues, ${ }^{36}$ but it is instructive to examine in more detail the approach other states and provinces are taking to Offshore Wind.

\footnotetext{
${ }^{30}$ Energy for Prosperity in Quebec supra note 17 at 15.

${ }^{31}$ Hydro-Quebec Distribution, Inventory of bids A/O 2005-03 - Wind Energy - 2,000 MW, (October 19, 2007) available at http://www.hydroquebec.com/distribution/en/marchequebecois/ao 200503/pdf/inventaire en.pdf.

32 Press Release, Hydro Quebec, Tender call for 2,000 MW of wind power: Hydro-Quebec accepts 15 bids (May 5, 2008) available at http://www.hydroquebec.com/distribution/en/marchequebecois/index.html. ${ }^{33}$ Id.

${ }^{34}$ Shaw supra note 4 at 13-17.

${ }^{35}$ Developers stake wind claims supra note 26.

${ }^{36}$ Shaw supra note 4; Dwight Kanyuck supra note 5; CHANNEL WHITE, WIND ACTION GROUP, ONTARIO'S DeVelopment of OfFShORE WIND In the GReAt LAKES, (June 2007). All available at http://www.greengold.org/wind/legal.php.
} 


\section{B. Offshore Wind Development in North America}

Although there have been a number of proposals and efforts to develop Offshore Wind in North America, there are currently no facilities in operation or under construction. Two proposals had proceeded to the point of final decision making only to stall because of project costs (the Long Island Power Authority's (LIPA) Long Island Offshore Wind Park (LIOWP) and Delaware's Behoboth Beach project ${ }^{37}$ ) and one is continuing, now into its sixth year, to proceed through environmental impact reviews (Cape Wind in Massachusetts). Undaunted, two states, Texas and New Jersey, are attempting to attract Offshore Wind development, each with different approaches, and Ontario has recently opened up its renewable energy supply process to include Offshore Wind. This section discusses these efforts at developing Offshore Wind and how they may apply to a long-term strategy for NYGLOW.

\section{New Jersey}

New Jersey's Offshore Wind program has launched a comprehensive natural resource study and economic impact assessment for developing Offshore Wind and has solicited bids for a $350 \mathrm{MW}$ pilot Offshore Wind facility off the coast of southern New Jersey. By doing so, New Jersey has looked to successful Offshore Wind risk evaluation and assessment processes used in Denmark and Germany as their model for developing their Offshore Wind program. ${ }^{38}$ New Jersey hopes to avoid the siting issues that have slowed the Cape Wind project and the spare planning work associated with the Long Island Offshore Wind Park. ${ }^{39}$ This section describes the origins of New Jersey's program and how it plans to proceed.

In 2004, the Governor of New Jersey commissioned a Blue Ribbon Panel to assess the development of wind turbine facilities off the coast of New Jersey. ${ }^{40}$ The driving force for the formation of the Blue Ribbon Panel was the predicted deficit in state energy supply, concerns regarding increased reliance on polluting upwind energy sources imported from out of state, the increase in electrical costs associated with fossil fuel prices and transmission system congestion, concerns about the effect of rising sea levels on the state as a result of global warming, and the state's Renewable Portfolio Standard (RPS). ${ }^{41}$ The Blue Ribbon Panel was charged with assessing the economic costs

\footnotetext{
${ }^{37}$ The Delaware project is still under negotiation over proposed contract costs between the developer, local power company, and State regulatory agencies and may yet become approved and active. See Editorial, Offshore wind project should stay in talking stage a while longer, The Wilmington Delaware News Journal (November 18, 2007) available at http://www.delawareonline.com/apps/pbcs.dll/article?AID=/20071118/OPINION11/711180305/1112.

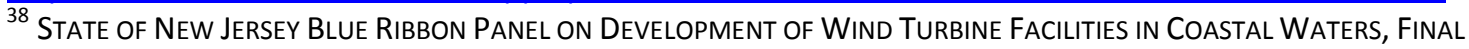
REPORT TO GOVERNOR JON S. CORZINE, 14-15 (April 2006) available at http://www.state.nj.us/njwindpanel/. ${ }^{39}$ Id.

${ }^{40}$ Id. at 1.

${ }^{41}$ Id. at 3-6. New Jersey's goal for renewable energy is $20 \%$ of total power supply by 2020.
} 
and benefits of developing Offshore Wind and recommending whether Offshore Wind was appropriate for New Jersey in comparison with other power sources. ${ }^{42}$

The Blue Ribbon Panel urged a cautious, yet relatively aggressive approach to developing Offshore Wind, looking to the Danish and German experiences as models. The panel observed that while the onshore wind resource was not commercially viable in New Jersey, the offshore wind resource could eventually become economically viable and that, because no one renewable energy source would be sufficient to meet the state's Renewable Portfolio Standard, "offshore wind must function as one element of a multi-faceted solution that addresses New Jersey's energy needs." ${ }^{43}$ The Panel recommended a two-pronged approach. First, commission an environmental and economic baseline survey to 1) collect data on the presence, abundance, and migratory patterns of sea-life and avian species in the area designated for potential Offshore Wind development and 2) assess the economic impacts on human uses of the coastal area, including the impact on tourism and fisheries. ${ }^{44}$ Second, facilitate development of a commercial scale Offshore Wind pilot facility, not to exceed $350 \mathrm{MW}$, to provide operating data not only on the environmental and economic impact of Offshore Wind, but on its potential as a clean, renewable energy resource for the state. ${ }^{45}$ In comparison, note that Ohio has proposed a pilot scale Offshore Wind facility in Lake Erie of only $20 \mathrm{MW}$ that is intended more as a feasibility study. ${ }^{46}$ While the Blue Ribbon report does not provide much detail in regard to the basis for the maximum size of the $350 \mathrm{MW}$ pilot facility, there is an implication that the selected size is necessary to understand power generation costs, effects on the local transmission system, and the financial viability of a commercial scale project.

The Ecological Baseline Study, which was funded by the state with a budget of $\$ 4.4$ million, was awarded in November $2007^{47}$ and a report is expected September $2009 .^{48}$ The primary purpose of the baseline study is to identify the portions of the study area that are more or less suitable for Offshore Wind development based on an eighteen month ecological impact survey. ${ }^{49}$ The study area was defined as a 68 nautical mile section of southern New Jersey coastline extending out along the 100-foot depth

${ }^{42}$ Id. at 1.

${ }^{43}$ Id. at 6-7.

${ }^{44}$ Id. at 16.

45 Id. at 18.

${ }^{46}$ Cuyahoga County Regional Energy Task Force, Building a New Energy Future, Recommendations for a Lake ERie Offshore Wind Energy Demonstration Project and Research Center (February 8, 2007) available at http://www.cuyahogacounty.us/pdf/RegEnergyTF.pdf.

${ }^{47}$ GMI Awarded New Jersey Ocean/Wind Power Ecological Baseline Studies, North American Wind Power, (Nov. 15, 2007), http://www.nawindpower.com/naw/e107 plugins/content/content.php?content.1457.

${ }^{48}$ Solicitation for Research Proposals, Ocean/Wind Power Ecological Baseline Studies, New Jersey Department of Environmental Protection, Division of Science, Research, and Technology, 12(April 19, 2007) available at http://www.nj.gov/dep/dsr/ocean-wind/srp-wind-ocean.pdf.

${ }^{49}$ Id. at 2-4. 
contour, generally about twenty nautical miles off the New Jersey coast. ${ }^{50}$ This area was selected to exclude areas of the New Jersey coast with known constraints for Offshore Wind such as air restricted zones, significant water habitat, and shipping lanes. ${ }^{51}$ By collecting ecological data in advance of the development of Offshore Wind facilities and identifying areas that are suitable for development, New Jersey is attempting to address issues that have stalled projects such as Cape Wind as well as many land based wind energy projects. The risk of significant adverse environmental impacts, and associated financial risks for developers from siting approval delays and facility shutdowns, will therefore be substantially reduced.

New Jersey solicited bids for its pilot Offshore Wind facility in October 2007, and received three bids for $350 \mathrm{MW}$ facilities in March 2008. ${ }^{52}$ When recommending the pilot project, the Blue Ribbon Panel emphasized that the key driver for the pilot facility was that there were too many unknowns to characterize the appropriateness of Offshore Wind in New Jersey ${ }^{53}$ and that, while planning for the pilot project should proceed with caution, the unknown or uncertain impacts can only be assessed through observation from the practical experience gained through the pilot project. ${ }^{54}$ The pilot facility is, therefore, required to provide environmental monitoring and natural resource data collection prior to, during, and following construction to ensure the necessary data to make the determination of the appropriateness of Offshore Wind. ${ }^{55}$ The solicitation further emphasizes that key factors in the evaluation of bids include the demonstration of the ability of the project to use adaptive management to avoid adverse environmental and ecological impacts and a public participation strategy indicating that the projects will likely be accepted by the surrounding community. ${ }^{56}$

As an incentive to developers to provide what is essentially a commercial scale research project, New Jersey provides some economic development incentives, but also includes some local content factors in their project evaluation criteria. The New Jersey Economic Development Authority (NJEDA), through the New Jersey Clean Energy

\footnotetext{
${ }^{50}$ Id. at 2.

${ }^{51}$ Id.

52 Solicitation for Proposals to Develop Off-Shore Wind Renewable Energy Facilities Supplying Electricity to the Distribution System Serving New Jersey, New Jersey Board of Public Utilities (October 5, 2007) available at http://www.njcleanenergy.com/files/file/OSWFinalSolicitation100507final.pdf. The three bidders were: PSEG Renewables Generation and Winergy Power Holdings, New Jersey's largest power company, proposing 96 turbines, 16 miles off shore; Bluewater Wind, who is also the proposed developer for an Offshore Wind facility in Delaware, proposing 116 turbines, 16 miles off shore; and Fisherman's Energy, a consortium of New Jersey fishing companies, proposing 74 turbines three to seven miles off shore. See Sandy Bauers, Three Proposed Wind Farms Off Jersey Shore, The Philadelphia Inquirer, (March 5, 2008) available at http://www.philly.com/inquirer/local/nj/20080305 Three propose wind farms off Jersey Shore.html, 53 Blue Ribbon Panel Final Report supra note 37 at 7.

${ }^{54}$ Id. at 14.

${ }^{55}$ Solicitation for Off-Shore Wind Facility supra note 51 at 6.

${ }^{56}$ Id. at 5-6.
} 
Program (NJCEP), is providing up to $\$ 19$ million in production incentives, paid out over five years, with up to $10 \%$ of the incentive paid up front for permitting and studies. ${ }^{57}$ In addition, the NJEDA is making tax-exempt bond financing available, ${ }^{58}$ and any tradable emission credits or tradable renewable energy certificates are the property of the developer, even though the project is partially financed through the NJCEP. ${ }^{59}$ While New Jersey does not state specific numerical targets for local content as Hydro-Quebec has, the solicitation does provide that, to "encourage[] the development and production of goods and services in the State . . ."60 the selection criteria includes " $[\mathrm{t}]$ he extent to which the technology and project will be manufactured in New Jersey and constructed by New Jersey based business ... [and] whether or not the technology was substantially manufactured in New Jersey." 61

New Jersey's approach to Offshore Wind development addresses issues that would have direct application to developing a strategy for NYGLOW. As in New Jersey, direct data regarding potential environmental and economic impacts of large scale Offshore Wind development, or, for that matter, defined geographical areas that are more or less amenable to development of Offshore Wind, are largely unknown or have not been comprehensively studied. Similarly, the development potential of the Offshore Wind resource in New York's Great Lakes is not clear, and both states have an interest in the economic development benefit of Offshore Wind. As New Jersey has done, strong consideration should be given to a comprehensive, State funded environmental and economic baseline data study to identify areas more amenable to NYGLOW. By supporting this key aspect to the site selection process, New York would provide an opportunity to engage stakeholders in the initial evaluation, reduce the risk of adverse environmental impacts, and reduce the financial risk to developers. Furthermore, supporting a commercial scale pilot project in New York's Great Lakes will not only provide practical experience and data regarding the environmental and economic impacts of Offshore Wind, but could potentially make New York a leader in Offshore Wind technology by successfully operating the first commercial fresh water Offshore Wind facility in the world.

\section{Texas}

In contrast to New Jersey's approach of funding extensive upfront research and financial incentives for a pilot project, Texas' approach to Offshore Wind development emphasizes its advantages to developers of a straightforward permitting and land acquisition process. Texas has entered into lease arrangements with developers for six parcels of Texas lands underwater in the Gulf of Mexico for Offshore Wind research and, ultimately, power generation. These leases are the result of Texas leveraging its

${ }^{57}$ ld. at 3.

${ }^{58} / d$.

${ }^{59} / d$. at 8 .

${ }^{60} / d$. at 13.

${ }^{61}$ Id. at 26. 
national leadership in wind energy production, a legal structure that supports offshore energy development, and the unique aspects of Texas land management and jurisdiction to promote Offshore Wind in Texas. This section describes Texas' approach to promoting Offshore Wind, as well as some of its shortcomings, and discusses how certain aspects of Texas' approach can be used for NYGLOW.

Driven by the state Renewable Portfolio Standard ${ }^{62}$ and the Texas General Land Office Plan for Sustainable Energy, ${ }^{63}$ Texas granted its first lease for lands underwater in the Gulf of Mexico for Offshore Wind power in 2005. ${ }^{64}$ Additional leases under similar terms were granted for one parcel in $2006^{65}$ and four more in $2007 .{ }^{66}$ Each lease is similarly structured, the most recent providing for a four-year research period for the contractor to perform environmental and wind resource studies, a construction period of up to five years, and a production period of 30 years. ${ }^{67}$ The developer may terminate the lease at any time following the research period ${ }^{68}$ and is required to make royalty payments to the Permanent School Fund based on a flat fee plus a percentage of the income from electricity generated throughout the 30 -year production period $(3.5 \%$ to $6.5 \%$ depending on the year of production). ${ }^{69}$

The most significant factor supporting Texas' progress in Offshore Wind is its full control over the granting of property rights to the lands underwater to be developed. Unlike New Jersey and most other Offshore Wind development efforts to date, Texas' Offshore Wind program is strictly within state territorial waters, ${ }^{70}$ thereby simplifying the granting of lands underwater to developers by eliminating the Federal government from any leasing terms. By controlling the leased underwater lands, Texas is also able to

\footnotetext{
${ }^{62}$ Goal for Renewable Energy, Tex. Util. Code Ann. §39.904(a) (Vernon 2007). In 2005, Texas expanded its renewable energy capacity target in its Renewable Portfolio Standard from 2,880 MW by 2009 to 5,880 MW by 2015.

${ }^{63}$ Texas General Land Office, Plan for Sustainable Energy, 3-4 (April 22, 2003) available at http://www.glo.state.tx.us/news/archive/2003/events/windpower/pdfs/Patterson\%20Wind\%20Energy\% 20Plan.pdf. The plan calls for promoting wind energy development, particularly through mapping the state's wind resource, including offshore.

${ }^{64}$ News Release, Texas General Land Office, Texas lands historic offshore wind project (October 24, 2005) available at http://www.glo.state.tx.us/news/docs/10-24-05-Offshore.pdf.

${ }^{65}$ News Release, Texas General Land Office, Patterson signs lease for biggest offshore wind farm in U.S. history, (May 11, 2006) available at http://www.glo.state.tx.us/news/archive/2006/docs/WL-2-PR-FINAL05-09-06.pdf.

${ }^{66}$ News Release: Texas awards first competitive wind leases in the United State, Texas General Land Office, (October 2, 2007) available at http://www.glo.state.tx.us/news/docs/2007-Releases/10-02-07wind-lease.pdf.

${ }^{67}$ Texas General Land Office, Wind Lease WL-, 13-14 (October 2, 2007) available at http://www.glo.state.tx.us/news/archive/2007/events/windlease 100207.html.

${ }^{68}$ Id. at 14.

${ }^{69}$ Id. at $17-19$.

${ }^{70} 43$ U.S.C. 1301(b) (2008). For Atlantic and Pacific coastal areas in the United States, state jurisdiction extends to three miles from the state coastline. State waters into the Gulf of Mexico, however, extend to three leagues from the state coastline. State waters into the Great Lakes extend to the international boundary with Canada.
} 
benefit financially from the proceeds of the lease, which under Texas law is designated for the Texas educational system through the Permanent School Fund. ${ }^{71}$ Ultimately, however, once the developer is prepared to proceed with the Offshore Wind facilities, approval must be obtained beyond Texas' authority. The Federal government continues to exert jurisdictional control by way of permit requirements for any structures or dredging associated with the Offshore Wind installation and Federal environmental reviews under the National Environmental Policy Act (NEPA) ${ }^{72}$ and Coastal Zone Management Act. ${ }^{73}$

Similarly, New York can directly lease lands underwater in the Great Lakes for Offshore Wind. New York holds title to the Great Lakes lands underwater to the international border with Canada ${ }^{74}$ and has in place statutory provisions to grant such leases through the Office of General Services. ${ }^{75}$ The availability of direct leasing, as in Texas, should therefore be attractive to developers, who only have to negotiate with the state for the use of the lands underwater. Furthermore, any income generated from the lease can be used to help promote public acceptance, such as contributing to an environmental protection fund for the Great Lakes. As in Texas, however, NYGLOW projects would require Federal permitting, environmental review, and coastal zone management review. ${ }^{76}$

The other key advantage Texas has in the way of Offshore Wind development is that of one central, relatively independent agency with experience in energy development, responsible for administering all of Texas' public lands, including Texas' lands underwater. ${ }^{77}$ This agency, the Texas General Land Office (GLO), is relatively independent, within its statutory authority, because the Commissioner of the GLO is an elected official at the state level, and does not report to the relatively weak office of the Governor. ${ }^{78}$ Additionally, the GLO has established a leadership role in the state in the area of wind energy because much of Texas' wind energy development has occurred on the extensive public lands administered by the GLO and the agency has substantial

\footnotetext{
${ }^{71}$ Press Release, Texas awards first competitive wind leases in the United States supra note 65.

72 Permits for Dredged or Fill Material, 33 U.S.C. 1344 (2008); National Environmental Policy Act 33 C.F.R. Pt. 230 (2008).

${ }^{73} 16$ U.S.C. $\$ 1456$ (c) (2008).

${ }^{74} 43$ U.S.C. 1301 (b) supra note 69.

${ }^{75}$ N.Y. COMP. CODES R. \& REGS. tit. 9, §270-1.1 (2007). For a more detailed explanation of leasing requirements with the OGS, see Kanyuck supra note 5 at 10-11.

${ }^{76}$ See Kanyuck supra note 5 at 7, 13-17.

${ }^{77}$ See generally Tex. Nat. Res. Code Ann. Ch. 31 (2008); See also About the Land Office, Texas General Land Office, http://www.glo.state.tx.us/about/landoffice.html, (last visited May 3, 2008).

${ }^{78}$ See Tex. Nat. Res. Code Ann. Ch. 31; See also Texas Politics, The Executive Branch, Commissioner of the General Land Office, Liberal Arts Instructional Technology Services, University of Texas at Austin, Chapter 9.5 (2005) available at http://texaspolitics.laits.utexas.edu/html/exec/0905.html.
} 
experience in the area of general energy development from its authority over the granting of mineral rights. ${ }^{79}$

While New York does not have a single agency with the equivalent authority or independence of the GLO, it does have two state public authorities (the New York Power Authority (NYPA) and New York Energy Research and Development Authority (NYSERDA)) with a primary mission in energy development and production, as well as the power to acquire property rights, and a state agency (the Office of General Services (OGS)) with sole authority for granting lease rights to New York's lands underwater. The powers of NYPA, NYSERDA, and the OGS will be discussed in more detail in Section D.1, infra, but it is clear that, collectively, they possess authority similar to the Texas GLO that can streamline NYGLOW.

Some caution is appropriate in assessing the progress Texas has made in the area of Offshore Wind. Although Texas has generated a fair amount of publicity through its Offshore Wind leases, it is by no means certain that actual production facilities will result. One of the six leases, issued to Superior Renewable Energy in 2006, was terminated by the developer because they "[did not] see the economics working offshore in Texas," indicating that Offshore Wind would be more economically viable in eastern states because of significant restraints on land development and higher energy prices. ${ }^{80}$ Furthermore, only one developer holds the remaining five leases and the "competitive bid" process for the 2007 leases yielded only one bidder. ${ }^{81}$ These factors imply that, while Texas' streamlined leasing process may be beneficial to initiate the development process, it alone may not sufficient to make Offshore Wind economically viable. Furthermore, as discussed supra, Federal approval of any plans will ultimately be required.

Ultimately, New Jersey and Texas may represent the tortoise and hare of Offshore Wind development. Cautious, upfront, state driven research and development compared with a largely open grant to developers with the charge of coming back within four years with a proposal. New York is in a unique position of being able to utilize the attributes of both approaches for NYGLOW.

\footnotetext{
${ }^{79}$ Texas General Land Office, Sustainable Energy Strategy for a New Century, http://www.glo.state.tx.us/energy/sustain/index.html (last visited May 3, 2008).

${ }^{80}$ Developer Nixes Offshore Wind Farm, Wind Energy News (June 12, 2007) http://www.windenergynews.com/content/view/770/43/. Additionally, strong demand remains in Texas for more economical on-land wind development as evidenced by the $\$ 10$ billion, 4,000 MW wind farm proposed by Texas oil man T. Boone Pickens and a 3,000 MW wind farm proposed by Shell Oil and the TXU Corporation for the Texas panhandle. See Clifford Krauss, Move Over Oil, There's Money in Texas Wind, New York Times (Feb. 23, 2008) available at http://www.nytimes.com/2008/02/23/business/23wind.html?em\&ex $=1204002000 \& e n=3 e 2 e 15 d 592317$ $1 \mathrm{a} 4 \&$ ei $=5070 \&$ pagewanted=all.

${ }^{\frac{1}{81}}$ Texas lands historic offshore wind project supra note 63; Texas awards first competitive wind leases in the United States supra note 65; Texas awards rights for offshore wind farm, MSNBC (October 3, 2007) http://www.msnbc.msn.com/id/21113169/.
} 


\section{Ontario}

After a 14-month moratorium on processing applications for Offshore Wind, ${ }^{82}$ the Province of Ontario Ministry of Natural Resources (MNR) has established a process and guidelines for developing Offshore Wind facilities in Ontario's Great Lakes and lifted the moratorium in January 2008. ${ }^{83}$ Fourteen Offshore Wind projects are currently proposed and, as they would be for NYGLOW, all are located either in Lake Ontario or Lake Erie, and include such large proposals as the $710 \mathrm{MW}$ Trillium Power Wind I project in eastern Lake Ontario ${ }^{84}$ and a Toronto Hydro Corp. proposal for a $200 \mathrm{MW}$ project just east of Toronto. ${ }^{85}$ While none of these projects is currently beyond a research phase, the interest of developers to proceed with site assessment is a positive indication that the wind resource potential of the Great Lakes, the climate for renewable energy development in Ontario, and a clear process providing a path to development will likely lead to Offshore Wind in Ontario's Great Lakes.

Ontario has been aggressively pursuing additional renewable energy generating capacity since $2003 .{ }^{86}$ The current 20 -year plan for ensuring the "adequacy and reliability of electrical supply," ${ }^{87}$ referred to as the Integrated Power System Plan (IPSP), includes directives for renewable energy supply (RES) by the Ontario Ministry of Energy as part of the desired mix of conservation, electrical power generation and distribution. ${ }^{88}$ The IPSP calls for meeting Ontario's future energy needs through energy efficiency programs that reduce peak demand by 6,300 MW, adding about 8,000 MW of RES above the 2003 baseline of about 7,702 MW, maintaining Ontario's nuclear

\footnotetext{
${ }^{82}$ For a background of the basis for the offshore wind development moratorium in Ontario, see CHANNEL White, ONTARIO's DeVelopMent OF OfFSHORE WIND IN THE GREAT LAKES, 13-14 (June 2007) available at http://www.greengold.org/wind/documents/112.pdf.

${ }^{83}$ News Release, Ontario Ministry of Natural Resources, Ontario Lays Foundation for Offshore Wind Power; Moratorium on Applicants of Record to be Lifted (Jan. 17, 2008) available at http://www.mnr.gov.on.ca/en/Newsroom/LatestNews/MNR E004126.html.

${ }^{84}$ The Great Lakes May Soon be Home to Offshore Wind, Renewable Energy Access.com, http://renewableenergy.name/rea/news/story?id=51365, (Feb. 6, 2008). For a detailed description of the Trillium I proposal see White supra note 81 at 10.

${ }^{85}$ Ontario to approve Great Lakes wind power, Toronto Star (Jan. 15, 2008) available at http://www.thestar.com/News/Ontario/article/294044.

${ }^{86}$ Ontario Power Authority, The Integrated Power System Plan for the Period 2008-2027, 9 (October 19, 2007) available at http://www.powerauthority.on.ca/ipsp/Page.asp?PageID=122\&ContentID=6184\&SiteNodeID=320\&BL Ex pandID=. ONTARIO POWER AUTHORITY, A PROGRESS REPORT OF ELECTRICITY SUPPLY, 3 (January 2008) available at http://www.powerauthority.on.ca/Storage/65/6055 Progress Report on Electricity Supply January 2008.pdf. Report discusses individual contracts, Ontario's Standard Offer Program, and contains detailed status of projects under construction.

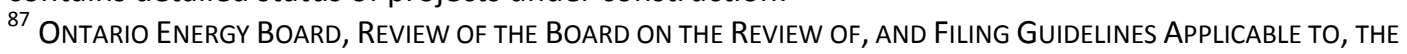
Ontario Power Authority's Integrated PoWer System Plan ANd Procurement Process, 2 (December 27, 2006) available at http://www.powerauthority.on.ca/ipsp/Storage/48/4389 A-3-1.pdf.

${ }^{88}$ Letter from David Duncan, Minister of Energy, Province of Ontario to Dr. Jan Carr, Ontario Power Authority, Integrated Power System Plan (The Supply Mix Directive) (June 13, 2006) available at http://www.powerauthority.on.ca/Storage/23/1870 IPSP-June13\%2C2006.pdf.
} 
facilities, but not expanding their capacity beyond the current level of $14,000 \mathrm{MW}$, eliminating coal-fired power generation by 2014 , providing limited natural gas fired generation for peak loading and high value uses, and upgrading the electrical distribution system to accommodate renewable energy development. ${ }^{89}$ The priority for selecting proposals for additional RES is based solely on feasibility and economics and gives priority to, in order of preference, 1 ) hydroelectric projects, 2) bioenergy, wind, and solar projects of less than $10 \mathrm{MW}$, and 3) large wind energy projects. ${ }^{90}$

The IPSP establishes an interim goal for the procurement of 2,700 MW of RES over the 2003 baseline of 7,702 MW by 2010, ${ }^{91}$ of which wind energy has or will contribute $780 \mathrm{MW}^{92}$ Wind energy is further expected to contribute an additional $3,905 \mathrm{MW}$ of power generation by 2027 , of which $866 \mathrm{MW}$ is already committed..$^{93}$ With the lifting of the MNR moratorium on Offshore Wind projects, Offshore Wind in Ontario's Great Lakes may become a feasible and economically attractive component of the RES procurement strategy because of proximity to population centers and the transmission grids along the lakeshores and the Great Lakes' strong, consistent wind speeds. $^{94}$

The MNR moratorium on Offshore Wind projects that began in November 2006 was a response to strong opposition to Lake Erie Offshore Wind project proposals and was intended to allow time for the agency to develop an environmental assessment process for commercial Offshore Wind development. ${ }^{95}$ The moratorium provided MNR with the opportunity to perform studies of offshore wind potential in Lakes Erie, Huron, and Ontario, including depth, wind speed, and social and ecological issues.

Additionally, guidance documents for birds and bats were developed and a database set up for monitoring wind power impacts on birds and bats. ${ }^{96}$ The environmental studies have been integrated into Ontario's Environmental Assessment process through special considerations that developers must address when proposing Offshore Wind facilities. ${ }^{97}$

\footnotetext{
89 The INTEgrated Power System Plan for the Period 2008-2027, Ontario Power Authority, 1-2 (October 19, 2007) available at http://www.powerauthority.on.ca/ipsp/Page.asp?PagelD=122\&ContentID=6184\&SiteNodelD=320\&BL Ex pandID $=$.

${ }^{90}$ Id. at 8.

${ }^{91}$ Id.

92 Id. at 9.

${ }^{93} \mathrm{ld}$.

${ }^{94}$ See generally White supra note 81 at 2-3.

95 Id. at 12-15.

${ }^{96}$ Ontario Lays Foundation for Offshore Wind supra note 81; Ontario Ministry of Natural Resources, Windpower: The Prepared Digital Maps, https://www.extranet.mnr.gov.on.ca/renewable/windpowernew/hardcopymap.html, (last visited May 3, 2008) (registration and password required); Ontario Ministry of Natural Resources, Windpower Policies and Procedures, https://www.extranet.mnr.gov.on.ca/renewable/windpower-new/policy.html, (last visited May 3, 2008) (registration and password required).

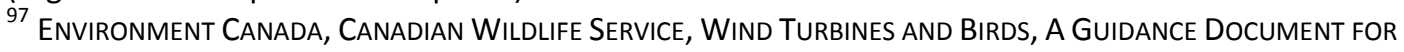
ENVIRONMENTAL ASSESSMENT, $\S 8.5,10.5$ (February 2007) available at
} 
These special considerations include more specific requirements for monitoring migratory bird activity and habitat changes, including, as minimum requirements, a twoyear pre-construction baseline study and a two-year post-construction baseline study (three years in ecologically sensitive areas). ${ }^{98}$ This approach supports our proposal for a systematic analysis of environmental considerations through a GEIS type process. ${ }^{99}$

Although Ontario's approach to establishing criteria for environmental assessment may be similar to New Jersey's intended approach, its approach to providing incentives and siting Offshore Wind projects is more closely related to Texas'. Like Texas, Ontario has provided a clear path to Offshore Wind development, through the IPSP procurement process, ${ }^{100}$ and has title to, and the ability to lease, the lands underwater for Offshore Wind development. ${ }^{101}$ Also like Texas, Ontario has not provided financial incentives specific to Offshore Wind, nor has it proposed the construction of a pilot facility, but Canada provides incentives for large-scale wind energy development, including a ten-year, $1.0 \mathrm{cent} / \mathrm{kw}$-hr incentive payment for renewable power generation, ${ }^{102}$ similar to but broader than the U.S. REPI program (see infra Section C.1), and Ontario provides accelerated depreciation incentives. ${ }^{103}$

The Request For Proposal (RFP) procedure within the IPSP Procurement Process is the primary vehicle for procurement of RES, including large-scale (greater than 10 MW) wind energy projects. ${ }^{104}$ In an approach that resembles Quebec's call-for-tenders approach of procuring large lots of energy generating capacity using a competitive process, two large RFPs for RES have been announced and awarded to date. ${ }^{105}$ The first RES RFP awarded 395 MW of RES contracts in 2004, with a total investment of $\$ 700$ million, ${ }^{106}$ and the second awarded $975 \mathrm{MW}$ of RES contracts, including $650 \mathrm{MW}$ of wind

https://www.extranet.mnr.gov.on.ca/renewable/windpower-new/Environmental\%20Approvals.html (registration and password required).

98 Id.

${ }^{99}$ See generally Kanyuck supra note 5 .

${ }^{100}$ See generally ONTARIO POWER AUtHORITY, IPSP PROCUREMENT Process, EB-2007-0707, Exhibit B, Tab 2 (2007) available at http://www.powerauthority.on.ca/ipsp/Page.asp?PagelD=122\&ContentID=6184\&SiteNodelD=320\&BL Ex pandID $=$.

${ }^{101}$ Ontario Ministry of Natural Resources, Application ReVIEW AND LAND Disposition Process, POLICY PL 4.02.01, § 3.1 (June 7, 2005) available at http://publicdocs.mnr.gov.on.ca/View.asp?Document ID=2294\&Attachment ID=7533.

${ }_{102}$ Natural Resources Canada, ECOEnergy for Renewable Power, 6,15 (April 2007) available at http://www.ecoaction.gc.ca/ecoenergy-ecoenergie/power-electricite/conditions-eng.pdf.

${ }^{103}$ Accelerated Capital Cost Allowance for Clean Energy Generation, Budget 2007, Annex 5Tax Measures: Supplementary Information and Notices of Ways and Means Motions, http://www.budget.gc.ca/2007/bp/bpa5ae.html.

${ }_{104}$ IPSP Procurement Process supra note 99 at Exhibit B, Tab 2.

105 Ontario Power Authority, Renewables RFPs Homepage, http://www.ontarioelectricityrfp.ca/Index.aspx?id=53, (last visited May 3, 2008).

${ }^{106}$ Ontario Power Authority, Renewables I Homepage, http://www.ontarioelectricityrfp.ca/Index.aspx?id=52, (last visited May 3, 2008). 
power, with a total investment of $\$ 2$ billion, in $2005 .{ }^{107}$ The next phase of the RES RFP process is expected to be for a total of $2,000 \mathrm{MW}$ of RES and announced in $2008 .{ }^{108}$

The RFP RES proposal evaluation criteria is a three step process that first evaluates the completeness of the application, then considers whether the project is technically sound, that it has sufficiently developed in the planning process--including having commenced the environmental assessment process--to become commercial by the RFP target date (Oct. 31, 2008 for the 2005 RFP), and whether the developer meets financial requirements for capitalization. ${ }^{109}$ Once the proposal passes this feasibility assessment, contracts are awarded solely based on proposal price unless a proposal affects a restricted power transmission zone. ${ }^{110}$ Unlike the Quebec process, however, Ontario does not include local content requirements in its evaluation process.

As a potential partner and competitor to NYGLOW, Ontario's process for Offshore Wind development has elements that have application to NYGLOW. Ontario's upfront environmental studies and environmental assessment protocols have provided the opportunity for early stakeholder involvement and concrete requirements for developers to plan for and meet. Ontario's clear procurement procedure for leasing lands underwater, as well as obtaining power contracts, provides developers with the predictability needed to obtain financing. New York, because of its ability to lease the lands underwater of its Great Lakes and authority granted to NYPA, discussed infra, has the potential to develop similarly clear processes. Additionally, New York and Ontario could mutually benefit from shared environmental and wind resource information for their shared Great Lakes, as well as partnerships in technology and manufacturing.

\section{Cape Wind-Massachusetts}

While it is arguable whether Cape Wind should be categorized as "making progress," it has progressed further through the review and approval process than any other Offshore Wind project in the United States. The project was proposed in 2001 as the first offshore wind facility in the United States and would provide a $468 \mathrm{MW}$ wind energy park in Nantucket Sound. ${ }^{111}$ Cape Wind was immediately met with well-funded

\footnotetext{
${ }^{107}$ Ontario Power Authority, Renewables II Homepage, http://www.ontarioelectricityrfp.ca/Index.aspx?id=42, (last visited May 3, 2008).

108 Ontario Power Authority, Renewable Energy Supply (PhASe III), REQUeST FOR EXPRESSIONS Of INTEREST, 2-4 (November 20, 2007), available at http://www.powerauthority.on.ca/GP/Page.asp?PagelD=122\&ContentID=696\&SiteNodelD=180\&BL Expa ndID $=$.

${ }^{109}$ Ontario Ministry of Energy, Request for Proposals for up to 1,000 MW of Renewable Energy Supply, 734 (June 17, 2005) http://www.ontarioelectricityrfp.ca/docs/ConsolidatedFinalRenewablesIIRFP3.pdf. 110 ld. at 8-10.

${ }^{111}$ MMS Offshore Minerals Management, Alternative Energy Programs, Projects: Cape Wind Energy Project, http://www.mms.gov/offshore/AlternativeEnergy/CapeWind.htm (last updated May 2, 2008); Minerals Management Service, Cape Wind Energy Project, Draft EnVIRonmental Impact Statement, Executive
} 
resistance based on concerns over aesthetics and recreational boating, exacerbated by jurisdictional ambiguity and an inadequate strategy for gaining public acceptance. ${ }^{112}$ Nevertheless, Cape Wind has continued to progress.

Through the Energy Policy Act of 2005, the Minerals Management Service (MMS) has obtained jurisdiction over alternative energy projects on the Outer Continental Shelf, including the Cape Wind project, thereby settling the problem of jurisdictional ambiguity. ${ }^{113}$ A Draft Environmental Impact Statement (DEIS) was issued by MMS for Cape Wind in January $2008,{ }^{114}$ however, it was well behind its original planned completion date of the winter of $2006 .{ }^{115}$ Cape Wind did receive final environmental review approval by the Massachusetts Office of Environmental Affairs under the Massachusetts Environmental Policy Act (MEPA) in March 2007. ${ }^{116}$ While the scope of this review was limited to the portions of the project associated with Massachusetts' jurisdiction, primarily the routing of transmission lines on land and within three miles from the Massachusetts coast, ${ }^{117}$ the Secretary did express the opinion that "the project represents a balanced and thoughtful commitment to action that will contribute to the long-term preservation and enhancement of our environment." ${ }^{\text {118 }}$

While the state now appears to be supportive, local approvals for Cape Wind have remained contentious. Cape Wind recently was denied a permit for transmission line routing by the Cape Cod Commission, a local commission responsible for oversight of natural resource development on Cape Cod, for lack of sufficient information. ${ }^{119}$ While the Cape Wind supporters accused the Commission of holding Cape Wind to higher standards than other projects and being bought out by interests opposed to the project, the Commission, which has a reputation for stringent developer review, countered that Cape Wind had given it insufficient time and information to properly

SUMMARY, 1-1 to 1-5 (August 2004) available at

http://www.mms.gov/offshore/AlternativeEnergy/CapeWindDEIS.htm.

${ }^{112}$ See Wendy Williams and Robert Whitcomb, Cape Wind (2007); Elinor Burkett, A Mighty Wind, New York Times Magazine, June 15, 2003, at 48 available at http://query.nytimes.com/gst/fullpage.html?res=9804E6DE1239F936A25755C0A9659C8B63; See generally Kanyuck supra note 5 at 2-4.

${ }^{113}$ Energy Policy Act of 2005, Pub. L. No. 109-58, §202, 119 Stat. 594. 654 (2005).

${ }^{114}$ CAPE Wind DRAft EnVIRONMENTAL IMPACt StATEMENT, U.S. DePARTMENT OF THE INTERIOR, Minerals MANAGEMENT SERVICE (January 2008) available at http://www.mms.gov/offshore/AlternativeEnergy/CapeWindDEIS.htm.

${ }^{115}$ Press Release, Minerals Management Service, MMS to Extend Comment Period on Cape Wind Energy Project Notice of Intent, (July 13, 2006), http://www.mms.gov/ooc/press/2006/press0713.htm.

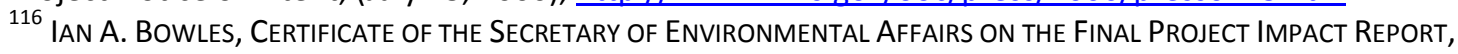
CApe Wind Project, The Commonwealth of Massachusetts Executive Office of Environmental Affairs, (March 29, 2007) available at http://www.mass.gov/envir/mepa/pdffiles/certificates/032907/12643feir.pdf.

117 Id. at 3.

118 Id. at 1.

${ }^{119}$ Stephanie Ebbert, Cape Cod panel denies permit for wind farm, The Boston Glove (October 19, 2007) available at http://www.boston.com/news/local/articles/2007/10/19/cape cod panel denies permit for wind far $\mathrm{m} /$. 
review the project. ${ }^{120}$ Cape Wind has appealed the Commission decision to the State, and is attempting to bypass other local approvals, by petitioning the Massachusetts Energy Facilities Siting Board to consolidate and approve the eight remaining local and state permits awaiting approval. ${ }^{121}$ While a strategy of obtaining local approvals through appeal to State agencies may be legally expedient, it further demonstrates how the lack of an early strategy for public acceptance continues to haunt Cape Wind to this day and is the primary lesson that Cape Wind offers in developing a strategy for NYGLOW.

\section{New York-Long Island}

The Long Island Power Authorities' (LIPA) Long Island Offshore Wind Park (LIOWP) was initiated in 2001 following a request by a coalition of community and environmental groups that LIPA study the feasibility for Offshore Wind off the coast of Long Island. ${ }^{122}$ Following a promising feasibility study conducted by the New York Energy Research and Development Authority (NYSERDA), ${ }^{123}$ LIPA issued a request for proposals in 2003 for a 100 to $144 \mathrm{MW}$ Offshore Wind facility off the southern shore of Long Island. ${ }^{124}$ The NYSERDA study had estimated that a $100 \mathrm{MW}$ Offshore Wind facility would have a cost of about $\$ 150$ to 180 million. ${ }^{125}$ In 2004, after receiving two qualified proposals, LIPA approved the proposal of Florida Power and Light (FPL) for a $144 \mathrm{MW}$ facility ${ }^{126}$ for an estimated $\$ 356$ million, ${ }^{127}$ however, the total cost of the project had not been finalized at that time. ${ }^{128}$ LIOWP proceeded steadily through the environmental review and permitting processes, ${ }^{129}$ helped by generally strong support from the local

\footnotetext{
${ }^{120} / d$.

${ }^{121}$ See Stephanie Ebbert, Cape Wind seeks to escape permit wars, The Boston Globe (November 22, 2007) available at http://www.boston.com/news/local/massachusetts/articles/2007/11/22/cape wind seeks to skip per mit wars/; Mike Seccombe, Town Objects to Cape Wind, Vineyard Gazette Online, http://www.mvgazette.com/article.php?15935 (April 4, 2008) (Town of Edgarton joins Yarmouth and Barnstable in contesting authority of Energy Facilities Siting Board to supercede local approval powers of Cape Cod Commission).

${ }^{122}$ See generally Shaw supra note 4 at 9.

${ }^{123}$ News Release, Long Island Power Authority, LIPA/NYSERDA Study Shows Offshore Wind Generation Has Significant Potential for Long Island (April 22, 2002) available at http://www.lipower.org/newscenter/pr/2002/april22 02.html.

124 Pace Global Energy Services, AsSessment of OfFShore Wind PoWer Resources, Long IsLAND POWER Authority, 6 (August 22, 2007) available at http://www.lipower.org/newscenter/pr/2007/pace wind.pdf.

${ }^{125}$ LIPA/NYSERDA Study supra note 122.

${ }^{126}$ Pace Assessment of Offshore Wind supra note123.

${ }^{127}$ Frank Eltman, L.I. scrapping ocean wind park, USA Today (Aug. 24, 2007) available at http://www.usatoday.com/money/economy/2007-08-24-3675988172 x.htm.

${ }^{128}$ Pace Assessment of Offshore Wind Power supra note 123 at. 6.

${ }^{129}$ Press Release, Long Island Power Authority, LIPA/FPL Energy Submit Application for Offshore Wind Project to U.S. Army Corps of Engineers, (April 26, 2005) available at http://www.lipower.org/newscenter/pr/2005/042605 wind.html.
} 
community, several prominent environmental organizations, and New York state leadership. ${ }^{130}$

Late in 2006, however, FPL returned an estimate for LIOWP much higher than anticipated that ultimately led to project termination. The FPL estimate for construction costs had risen to $\$ 697$ million and, when cabling and interconnections costs were included, a total project cost of $\$ 811$ million. ${ }^{131}$ LIPA commissioned an independent evaluation of the FPL estimate (the "Pace Study") that confirmed that the FPL estimate for LIOWP was consistent with market conditions. ${ }^{132}$ Upon issuance of the Pace Study, the incoming Chairman of LIPA declared, "this project doesn't make economic sense" and recommended its termination with the promise to research more attractive wind energy proposals. $^{133}$

Two primary factors led to the recommendation to terminate the LIOWP project. First was a change in leadership at LIPA. The new Chair clearly emphasized the shortterm economics of LIOWP and would not shoulder ratepayers with the extra costs. ${ }^{134}$ The outgoing chairman, who had long championed the project, took a longer view. He pointed out that, even at the $\$ 811$ million price tag, LIOWP was the least expensive form of renewable energy available to Long Island and LIPA had committed by 2013 to produce $25 \%$ of its electricity from renewable sources. ${ }^{135}$ Furthermore, he emphasized that the Pace Study concluded the cost to ratepayers would average only $\$ 2.50$ per month. ${ }^{136}$

The second and perhaps more significant factor was that, because LIPA had not been forthcoming with project cost information, LIPA had not educated the public about how the benefits of the project were worth the extra costs. ${ }^{137}$ LIPA had resisted Freedom of Information Act requests and even the incoming Chairman had difficulty obtaining cost information. ${ }^{138}$ When the updated FPL estimate revealed that the project

${ }^{130}$ See Jennifer Weeks, Wind Resistance, onearth, Natural Resources Defense Council (Fall 2005), http://www.nrdc.org/Onearth/05fal/frontlines.asp.

${ }^{131}$ Press Release, Long Island Power Authority, LIPA Releases Pace Study on Offshore Wind Project Costs, (August 23, 2007) available at http://www.lipower.org/newscenter/pr/2007/082307 wind.html.

132 U.S. Offshore Wind Power Market Assessment and Project Cost Estimate, Memorandum from Pace Global Energy Services to Libby McCarthy, Chief Financial Officer, Long Island Power Authority, 1-2 (August 3, 2007) available at http://www.lipower.org/newscenter/pr/2007/pace memo.pdf.

133 Mark Harrington, LIPA Chief kills wind farm project, Newsday (August 23, 2007) available at http://www.windaction.org/news/11471.

${ }^{134}$ Blown Away, Newsday Editorial (August 24, 2007) available at http://www.windaction.org/opinions/11518.

${ }^{135}$ Richard Kessel, Chief Executive and President of LIPA, Take Another Look at Wind Power, Newsday Letter to the Editor (September 4, 2007) available at http://www.cleanpowernow.org/index.php?name=News\&file=article\&sid=638.

${ }^{136}$ Id.

137 Blown Away supra note 133.

138 Mark Harrington, Sparks between LIPA execs over costs, Newsday (June 7, 2007) available at http://www.windaction.org/news/10005. 
costs had doubled, even supporters were surprised. ${ }^{139}$ Had LIPA been forthcoming with cost information, it could have emphasized the relatively small additional cost to ratepayer's month bills but instead had to justify an unanticipated increase in project cost of nearly $\$ 400$ million.

The primary lesson to take from Long Island as it relates to developing NYGLOW is that upfront public education is necessary, not only to address environmental and economic development aspects of Offshore Wind, but to justify short term increases in electricity costs. As pointed out in the Pace Study, LIOWP costs were about $\$ 5,634$ per kilowatt of capacity, considerably higher than the costs in Europe of about $\$ 4,000$ per kilowatt of capacity. ${ }^{140}$ The Pace Study, however, pointed out that European costs are lower because of a competitive European market for offshore turbines and lack of specialty infrastructure in the United States for developing large-scale offshore facilities. ${ }^{141}$ Both of these factors should dissipate as a demand is developed in the U.S. for Offshore Wind installations. Furthermore, with cap and trade systems for carbon emissions present at the regional (see Regional Greenhouse Gas Initiative discussion Section C.3, infra) and, possibly, national levels, additional economic benefits for Offshore Wind projects will be provided in the form of carbon free energy credits. This therefore indicates that governmental financial support or cost spreading will be necessary in the short term to prevent local ratepayers shouldering the initial burdens of being at the forefront of a high potential renewable energy resource.

\section{Financial Incentives for Offshore Wind}

As discussed in the New York-Long Island section supra, as well as with experience in Europe, ${ }^{142}$ Offshore Wind is currently less financially attractive than land based wind energy facilities. Europe and the U.S., however, diverge in their response to this issue. Europe has recognized the potential benefits of Offshore Wind in comparison with land based wind development, particularly the greater wind resource availability and the increasingly limited availability of land based wind energy sites, and is providing the necessary incentives to enable Offshore Wind technology to mature and become a significant component of renewable energy and greenhouse gas emission reduction goals. ${ }^{143}$ The United States on the other hand, while recognizing the potential offshore wind resource available, has not, at least at the federal level, differentiated the need to develop offshore wind as part of its renewable energy strategy. This section discusses

\footnotetext{
${ }^{139}$ Mark Harrington, Environmentalist Differed on LIPA Wind Plan, Newsday (August 29, 2007) available at http://www.redorbit.com/news/science/1048566/environmentalist differed on lipa wind plan/index.h tml.

${ }^{140}$ Pace Assessment of Offshore Wind Power supra note 123 at 6.

${ }^{141}$ Id. at 6-7.

${ }^{142}$ See generally, OFFSHORE WIND FARMS IN EUROPE, KPMG (2007) available at http://www.kpmg.com.au/Portals/O/KPMG Offshore wind farms in Europe 2007.pdf. 
and compares the approaches to providing incentives for Offshore Wind in the U.S. and Europe, with an eye toward potential application to NYGLOW.

\section{U.S. Wind Energy Incentives}

Incentives specifically targeted to Offshore Wind in the United States have only been provided at the state level, as discussed in Section B supra. The federal government does not currently provide incentives specific to Offshore Wind, but does provide incentives for wind energy generally, as well as other selected renewable energy technologies, that are an important component to the financial viability of Offshore Wind projects in the U.S. These incentives include the Renewable Energy Production Incentive (REPI), ${ }^{144}$ the Production Tax Credit (PTC), ${ }^{145}$ and Clean Renewable Energy Bonds (CREBs). ${ }^{146}$ The incentives, however, have been hampered by concerns regarding renewal (for the PTC and CREBs) and funding availability (for REPI).

The PTC is a significant incentive for privately owned wind energy utilities having the tax appetite to utilize the credit and that will have facilities in operation prior to the expiration of the credit. The PTC is a federal tax credit for renewable energy production that provides an inflation indexed tax credit (from 1993) of up to 1.5 cents per kilowatthour of electricity generated from qualified energy resources for a ten year period beginning on the date the facility was placed in service. ${ }^{147}$ The available credit was 2.0 cents per kilowatt-hour in $2007^{148}$ and wind is considered to be a qualified energy resource. ${ }^{149}$ To be eligible for the credit, the facility generating wind-based electricity must by owned by the taxpayer ${ }^{150}$ and the power sold to an unrelated person during the taxable year. ${ }^{151}$ Among the advantages of the PTC is that, as a tax credit, it is not subject to annual swings in funding appropriation, so that once a generator places a facility in service, they can depend on the availability of the credit. An impediment to development has been that the PTC has not been reauthorized for the extended period necessary for the developers to depend on its availability when the facility is placed in service. ${ }^{152}$ For example, the PTC is currently only available to facilities put in service by January 1, 2009 as provided in the 2006 Amendment to the credit ${ }^{153}$ (which extended

\footnotetext{
${ }^{144} 42$ U.S.C. $\S 13317$ (2008); 10 C.F.R. Pt. 451 (2008).

145 I.R.C. $§ 45$ (2008).

${ }^{146}$ See I.R.C. $\S 56$ (2008); Internal Revenue Bulletin 2007-14, Notice 2007-26, Clean Renewable Energy Bonds (April 27, 2007) available at http://www.irs.gov/irb/2007-14 IRB/ar17.html.

${ }^{147}$ I.R.C. $§ 45(\mathrm{a})$.

148 I.R.S. Notice 2007-40, Credit for Renewable Electricity Production, Refined Coal Production, and Indian Coal Production, and Publication of Inflation Adjustment Factors and Reference Prices for Calendar Year 2007 (May 21, 2007).

${ }^{149}$ I.R.C. $\S 45(c)(1)(A)$.

150 I.R.C. $\S 45(d)(1)$.

151 I.R.C. $\S 45(a)(2)$.

152 Legislative Priorities, Production Tax Credit Extension, American Wind Energy Association, http://www.awea.org/legislative/\#PTC (last visited May 4, 2008).

${ }^{153}$ I.R.C. § 45(d)(1); Pub. L. 109-432, Div. A, Title II, 201 (2006).
} 
the availability date only one year from the 2005 Amendment to the act ${ }^{154}$ ) and reauthorization is uncertain.

Public utilities, on the other hand, have no tax appetite and, unless an arrangement is structured to involve a private generator, must instead rely on REPI to provide financial support for wind energy production. REPI provides public utilities and not-for-profit electrical cooperatives with the same inflation adjusted incentive as the PTC, currently 2.0 cents per kilowatt-hour, but in the form of an incentive payment to either the owner or operator of the qualified renewable energy facility, including wind energy facilities. ${ }^{155}$ The payments are authorized for 10 years from the first year of availability and, unlike the limited PTC authorization, REPI is authorized for facilities first put into service as late as October 1, 2016. ${ }^{156}$ Unfortunately, because REPI payments are subject the availability of annual appropriations, REPI has largely become a mirage as an incentive for public utilities attempting to develop qualified renewable energy facilities. During the last year of complete information (FY2005), only 32\% of the requested eligible payments for wind, solar, ocean, geothermal, and closed-loop biomass energy projects were paid. ${ }^{157}$ Furthermore, the FY2008 budget proposed by the Bush Administration "zeroes out" REPI program funding. ${ }^{158}$ Without a mechanism to ensure long term funding availability for REPI payments, publicly owned utilities interested in Offshore Wind are at a financial disadvantage compared with private Offshore Wind developers. Publicly owned utilities, therefore, may be pushed toward partnerships with private Offshore Wind generators instead of directly executing and operating Offshore Wind project in order to have access to the substantial financial incentive provided by the PTC.

Public Utilities also have the incentive provided by Clean Renewable Energy Bonds (CREBS) to defray the capitals costs associated with wind energy development. CREBS may be issued by electric cooperatives or government entities (and any subdivision thereof), and are issued at a $0 \%$ interest rate, ${ }^{159}$ so the borrower (the public utility) is only required to repay principal. The bondholder instead receives federal tax credits in lieu of the traditional bond interest payment based on rates set up by the Treasury and based on AA rated commercial bonds. ${ }^{160}$ The total national volume cap

\footnotetext{
${ }^{154}$ Pub. L. 109-58 § 1301(a) (2005).

${ }^{155} 42$ U.S.C. $\S 13317(\mathrm{a}),(\mathrm{d}),(\mathrm{e})(2008)$.

${ }^{156} 42$ U.S.C. $\S 13317$ (c).

${ }^{157}$ U.S. Department of Energy, Energy Efficiency and Renewable Energy, Renewable Energy Production Incentive, About the Program, http://www.eere.energy.gov/repi/about.cfm (last visited May 4, 2008).

158 U.S. DePARTMENT OF ENERGY, ENERGY EFFICIENCY AND RENEWABLE ENERGY, FISCAL YEAR 2009 BUDGET-IN-BRIEF, 54 (2008) available at http://www1.eere.energy.gov/ba/pba/pdfs/FY09 budget brief.pdf. The requested budget maintains, "the incentive value of REPI has diminished over time as renewable technologies have become more competitive. Also, the steadily growing pool of eligible applicants has resulted in increasingly small amounts which can be paid out, given the limited availability of funds to distribute. ${ }^{159}$ Treasury Bulletin 2007-14 supra note 145 at $\S 2$.

160 Id. at $\S 9$. See also Treasury Direct, Clean Renewable Energy Bond Rates, https://www.treasurydirect.gov/SZ/SPESRates?type=CREBS (last visited May 3, 2008).
} 
for the CREBs program of $\$ 1.2$ billion has been allocated as of February 8, 2008 among 922 projects (of 1,104 projects applied for), with awards determined on a smallest-tolargest request basis for qualified projects. ${ }^{161}$ Unfortunately, to date, the CREBs legislation has not been renewed, so the incentive associated with CREBs is as uncertain as that provided by the PTC or REPI.

\section{European Offshore Wind Incentives}

While the U.S. currently has no offshore wind energy facilities in operation, more than 1,000 MW of offshore wind capacity is in operation in Europe, mostly in Denmark and the U.K. ${ }^{162}$ An additional $484 \mathrm{MW}$ of Offshore Wind is under construction, and over $9,000 \mathrm{MW}$ is approved through 2011 , with most of the additional capacity centered on the U.K., Germany, and Ireland. ${ }^{163}$ The annual capital expenditure for Offshore Wind in Europe is expected to be over $\$ 5.2$ billion by $2012 .{ }^{164}$ The push for Offshore Wind in Europe is driven by the increasing scarcity of space for on-land wind energy development and the recognition of the opportunity to develop the considerable offshore wind resource as a significant component of meeting long-term renewable energy and greenhouse gas emission reduction targets. ${ }^{165}$ The desire to further promote Offshore Wind development in Europe has led to a number of countries providing incentives specific to Offshore Wind.

European countries have generally used some variation of the renewable feed-in tariff (Feed-In Tariff) approach to providing incentives for renewable energy development. ${ }^{166}$ A Feed-In Tariff system generally provides two components: access to the electricity grid and a minimum fixed price for electricity for a pre-determined term. ${ }^{167}$ Prices are set to provide sufficient investment return to produce the desired pace of development and vary widely by country based on such factors as technology, energy source, energy resource availability, size of the development, length of payments, and market pricing. ${ }^{168}$ While most European Union countries have some

\footnotetext{
${ }^{161}$ IR-2008-16, IRS Announces Energy Bond Allocations, Internal Revenue Service (February 8, 2008) available at http://www.irs.gov/newsroom/article/0,id=179016,00.html.

162 Offshore Wind Farms in Europe supra note 141 at 12.

163 Id. at 12.

164 DOUgLAS-WeStWOOd, THE WORLD OfFSHORE WIND REPORT 2008-2012 LEAFLET, (2007) available at http://www.dw-1.com/assets/documents/NEW\%20432\%200ffshore\%20Wind\%20leaflet\%20PDF.pdf.

${ }^{165}$ See e.g. Federal Ministry for EnVIRONMENT, NATURe Conservation, ANd Nuclear Safety (Germany), Renewable Energy SOURCES ACT; PRogress RePORT 2007,13-14 (Dec. 12, 2007) available at http://www.bmu.de/english/renewable energy/downloads/doc/40943.php; RISO NATIONAL LABORATORY, SUSTAINABLE ENERGY IRELAND, OfFSHORE WIND ENERGY AND INDUSTRIAL DEVELOPMENT IN THE REPUBLIC OF IRELAND, 1314 (October 2004) available at www.sei.ie/getFile.asp?FC ID=1721\&docID=65; Offshore Wind Farms in Europe supra note 141 at 28-29.

${ }^{166}$ See generally PAUL GIPE, ReneWABLE ENERgy Policy MeChANISMS, 18-25 (February 17, 2006) available at http://www.wind-works.org/FeedLaws/RenewableEnergyPolicyMechanismsbyPaulGipe.pdf.

${ }^{167}$ Id. at 18.

${ }^{168}$ /d. at 18-19.
} 
form of Feed-In Tariff for wind energy, ${ }^{169}$ only France, Germany, Spain, and Ireland are now offering premium tariffs for Offshore Wind. ${ }^{170}$ These premiums bring the Offshore Wind tariffs for these countries in line with those of the current Offshore Wind market leader, the U.K., which currently offers a total payment of $€ 0.1349 / \mathrm{kw}$-hr for all wind energy. ${ }^{171}$

Germany, for example, which projects 20,000 to 25,000 MW of Offshore Wind by the $2025 / 2030$ timeframe, ${ }^{172}$ has recently provided, and increased, their premium tariff for Offshore Wind. The German Renewable Energy Sources Act of 2004 provides that an "average" on-land wind facility commencing operation in Germany in 2009 will receive a tariff of $0.0795 € / \mathrm{kw}$-hr payable for a period of 12.4 years and $0.0502 € / \mathrm{kw}$-hr for 7.6 years. ${ }^{173}$ Updates to the Act have provided that Offshore Wind facilities, on the other hand, will receive a payment of $0.14 € / \mathrm{kw}-\mathrm{hr}$ for a period of 16 years with the payment dropping to $0.035 € / \mathrm{kw}$-hr for the following four years - a significant premium of 0.0605 to $0.0898 € / \mathrm{kw}$-hr for the first 16 years. ${ }^{174}$ Additionally, the premium payment is extended beyond 16 years for each mile the facility is sited beyond 12 miles from shore ( 0.5 months for each mile) and in waters deeper than 20 meters ( 1.7 months for each meter).

Similarly, France pays a tariff for "average" on-land wind facilities of $0.082 € / \mathrm{kw}$ $\mathrm{hr}$ for a period of ten years; dropping to $0.048 € / \mathrm{kw}$-hr for the following five years, while Offshore Wind facilities receive a tariff of $0.13 € / \mathrm{kw}-\mathrm{hr}$ for the first ten years of operation dropping to $0.09 € / \mathrm{kw}$-hr for the following five years-an Offshore Wind premium of $0.048 € / \mathrm{kw}-\mathrm{hr} .{ }^{175}$ Spain offers the greatest total tariff for Offshore Wind with a total payment of $0.1640 € / \mathrm{kw}$-hr at current market rates including an 0.0843 $€ / k w$-hr premium for Offshore Wind-with a term of payment of 20 years. ${ }^{176}$ Additionally, Ireland has just recently announced a payment of $0.14 € / \mathrm{kw}-\mathrm{hr}$ for a term

\footnotetext{
${ }^{169}$ Id. at 19-20.

170 Offshore Wind Farms in Europe supra note 141 at 20-27.

${ }^{171} / d$. at 23-25.

${ }^{172}$ Federal Ministry for the Environment, Nature Conservation, and Nuclear Safety (Germany), General Information-Renewable Energy, http://www.bmu.de/english/renewable_energy/general_information/doc/4306.php (last visited May 4, 2008).

${ }^{173}$ Renewable Energy Sources Act (Germany), Article 10 (2004) available at http://www.bmu.de/english/renewable energy/doc/6465.php; See also Paul Gipe, Tables of Renewable Energy Tariffs or Feed-In Tariffs Worldwide, (December 20, 2007) available at http://www.windworks.org/FeedLaws/TableofRenewableTariffsorFeed-InTariffsWorldwide.html. works.org/FeedLaws/France/FrancelmplementsNewRenewableTariffsforSolarWindandBiogas.html (July 26, 2006).

${ }^{176}$ Offshore Wind Farms in Europe supra note 141 at 29.
} 
of 15 years ${ }^{177}$ as contrasted with a $0.059 € / \mathrm{kw}$-hr tariff for on-land wind energy facilities-an $0.081 € / \mathrm{kw}$-hr premium for Offshore Wind. ${ }^{178}$

With the above tariff premiums in the $0.08 € / \mathrm{kw}$-hr range for Offshore Wind, developers have indicated that the above markets are attractive to Offshore Wind development, especially in markets, such as Great Britain, Germany, and Ireland, where there is also significant geographical data available. ${ }^{179}$

\section{RGGI and Offshore Wind Incentives in New York}

To date, New York has not provided any incentives specific to Offshore Wind, but the first report of then Lieutenant Governor Patterson's Renewable Energy Task Force (the "Task Force") has recommended that incentives be provided for "review[ing] the possibilities for siting Offshore Wind in New York's Great Lakes," because of the substantial resource potential, high load factors, and proximity to high load areas. ${ }^{180}$ The Regional Greenhouse Gas Initiative (RGGI) is a potential source of revenue to support this incentive program.

RGGI is an agreement between eight northeast and mid-Atlantic U.S. States to establish a cap and trade system to reduce greenhouse gas (GHG) emissions from fossil fuel fired electrical power generating plants (greater than $25 \mathrm{MW}$ ) within each state. ${ }^{181}$ The scheme includes, at its foundation, the issuance of each state's budget for GHG emissions in terms of tons of carbon dioxide (CO2) emissions per year. ${ }^{182}$ Each annual ton of $\mathrm{CO} 2$ emissions in New York's allocation will be auctioned to the regulated utilities or other permitted market participants as "Allowances", which then establish the quantity of $\mathrm{CO} 2$ emissions each utility will be allowed to emit annually. ${ }^{183}$ The proceeds from the auctions are to be used toward a "consumer benefit or strategic energy purpose ... to promote energy efficiency, ... directly mitigate electricity ratepayer impacts, ... promote renewable or non-carbon-emitting energy technologies, ... . stimulate or reward investment in the development of innovative carbon emission abatement technologies with significant carbon reduction potential, and/or fund the administration of the [RGGI] program." ${ }^{184}$

${ }^{177}$ Ireland to Support Offshore Wind Power, RenewableEnergyWorld.com, http://www.renewableenergyworld.com/rea/news/story?id=51620 (Feb. 20, 2008).

${ }_{178}$ Press Release, Department of Communications, Energy, and Natural Resources (Ireland), Minister Noel Dempsey announces new initiative to increase production of electricity from renewable energy technologies, (May 1, 2006) available at http://www.dcmnr.gov.ie/Press+Releases/Minister+Noel+Dempsey+announces+new+initiative+to+increa se++production+of+electricity+from+renewable.htm.

${ }^{179}$ Offshore Wind Farms in Europe supra note 141 at 31-32.

${ }^{180}$ Renewable Energy Task Force supra note 1 at 10.

${ }^{181}$ Regional Greenhouse Gas Initiative, Memorandum of Understanding, 2-3 (December 20, 2005) available at http://www.rggi.org/docs/mou final 1220 05.pdf.

182 Id. at 2-6.

183 Id.

${ }^{184}$ Id. 
New York has a budget of over sixty four million Allowances for $2009,{ }^{185}$ likely to first be auctioned in December 2008. ${ }^{186}$ Under the proposed New York regulation for managing the funds generated from the Allowances, NYSERDA would administer an "energy efficiency and clean energy technology account" (the "Account") to promote and reward investments in energy efficiency, renewable or non-carbon emitting technologies, and/or innovative carbon emissions abatement technologies with significant carbon reduction potential. ${ }^{187}$ With an estimated price for Allowances at the first auction expected to be $\$ 2.32$, and a "reserve price," representing the minimum acceptable price, set at $\$ 1.86$ per Allowance, ${ }^{188}$ the Account would receive at least $\$ 119$ million in 2009 and a likely amount of $\$ 148$ million.

Consistent with the recommendations of the Task Force, NYSERDA should direct a significant portion of the Account to provide incentives for Offshore Wind development and "review the possibilities" of NYGLOW. This could include grants, as in New Jersey's approach, to perform environmental studies to aid the site selection process and provide incentives for pilot Offshore Wind projects. Furthermore, NYSERDA could establish an incentive similar to that of the European feed-in tariffs, the federal Production Tax Credit or REPI to provide an ongoing incentive once the viability of NYGLOW is established.

\section{A Strategy for NYGLOW}

A strategy for a long term development process for NYGLOW, as mentioned above, should: 1 ) identify a prudent level of clean energy development that balances environmental, economic, and power generation issues, 2) provide an economic development engine that promotes Western New York as a leader in Offshore Wind manufacturing and technology and clean power generation, and 3) does so in a way that earns public acceptance. This section considers the current governmental structure in New York, the experiences of other states and countries discussed above, and addresses the questions: 1) who are the entities most capable of implementing a process that achieves success, 2) what steps are needed to begin the process, and 3) what governmental action and leadership is necessary to execute the strategy?

As discussed infra, each of the Offshore Wind and wind energy development efforts discussed above has application to a strategy for New York's Great Lakes.

\footnotetext{
185 Id.

${ }^{186}$ Press Release, Regional Greenhouse Gas Inititiative, Inc., Date Announced for Nation's First Auction of Greenhouse Gas Emissions Allowances, (March 17, 2008) available at http://www.rggi.org/docs/20080317news release.pdf.

${ }^{187}$ CO2 Budget Trading Program, (proposed 2007) (to be codified as 6 N.Y.C.R.R. Pt. 242), § 242-5.3, available at http://www.dec.ny.gov/regulations/38974.html.

${ }^{188}$ Regional Greenhouse Gas Initiative, Inc., Design Elements for Regional Allowance Auctions under the Regional Greenhouse Gas Initiative, 2 (March 17, 2008) available at http://www.rggi.org/docs/20080317auction design.pdf.
} 
The policies of Quebec demonstrate that the potential for access to a large wind energy market is an attractive incentive to developers and that these developers are willing to meet local investment requirements to gain access to a large market if the local region has sufficient manufacturing and technology infrastructure. Quebec also shows the benefits of integrating wind energy development with hydropower in such a way that optimizes the total quantity of renewable energy power generation, while maintaining electrical supply reliability requirements.

New Jersey's and Ontario's Offshore Wind strategy recognizes that the state has a role in obtaining the necessary data to understand the environmental and economic benefits and impacts of Offshore Wind development and that this understanding is essential in gaining public acceptance. New Jersey further recognizes that, without practical experience, much of that data are speculative and that a commercial scale facility is necessary to truly understand the environmental and economic considerations associated with Offshore Wind. New Jersey also recognizes, as do many European countries, that financial incentives, such as direct funding and tax-free bonds, are necessary to enable initial projects to be financially viable.

Texas and Ontario amplify some of the unique jurisdictional aspects of New York's Great Lakes that may be beneficial in streamlining the siting and development process. Like Texas and Ontario, granting leases for development of NYGLOW would be simplified because they are directly under the control of the state (with accompanying federal permit approvals). The income from these leases could be targeted in a manner to help offset any environmental impact that may result from Offshore Wind development. Furthermore, while New York does not have governmental agencies with quite the independence and authority of the Texas GLO or Ontario's OPA and MNR for Offshore Wind development, a coordinated effort between NYPA, NYSERDA, and the OGS, with appropriate state and local government support, would closely approximate the benefits to developers of dealing with only one entity, as Texas offers with the Texas GLO.

Cape Wind and LIOWP provide caution that transparency and public outreach are critical to gaining public acceptance. Cape Wind's problems arose from an insufficient early effort to understand local concerns regarding the environmental and aesthetic impact of the project. LIOWP, while more successful in addressing environmental and aesthetic concerns than Cape Wind, lost credibility and an opportunity to educate the public about the short term costs of Offshore Wind by not being forthcoming regarding project costs.

From these considerations, the following strategy is recommended.

\section{Who Should Implement the Process: NYPA and NYSERDA Have the Power}

As suggested above, the New York Power Authority (NYPA) and the New York State Energy Research and Development Authority (NYSERDA), with coordination with 
the Office of General Services (OGS), collectively have the statutory authority to initiate and implement NYGLOW. Furthermore, they have the potential to offer many of the "one-stop shopping" benefits of the Texas GLO and Ontario's OPA. This section discusses the mission and authority of NYPA and NYSERDA as it relates to NYGLOW.

NYPA was created in 1931 to "secure public control of New York's hydropower resources ..." and is the largest state-owned power organization in the United States. ${ }^{189}$ NYPA operates three large hydroelectric facilities in New York, on the Niagara and St. Lawrence Rivers and in the Catskill Mountains, with a total of 4,240 MW of net dependable capacity. ${ }^{190}$ In addition, NYPA operates numerous small hydroelectric and fossil fuel plants throughout the state. ${ }^{191}$ NYPA had operated the Indian Point 3 and James A. FitzPatrick nuclear power plants until they were sold to Entergy Corporation in $2000 .^{192}$

Part of the mission of NYPA is "to provide clean, economical, and reliable energy ... for the benefit of [its] customers and all New Yorkers." ${ }^{193}$ NYPA's statutory policy declaration includes "assisting in the ... development of advanced facilities having substantial prospects of reducing electricity production costs, the public interest requires that the authority participate in the generation of supplemental electric power and energy by ... new energy technologies . ..."194

NYPA's implementing statute defines it as a corporate municipal instrumentality that is a political subdivision of the state, exercising governmental and public powers. ${ }^{195}$ NYPA is governed by seven trustees who serve five-year terms and are appointed by the governor with the advice and consent of the senate. ${ }^{196}$ The authority can self-finance their projects through bond issues. ${ }^{197}$ NYPA has the authority to acquire interests in real property, including lands underwater, and to find that such property is required for public use and that such public use "shall be deemed superior to the public use in the hands of any other person, association, or corporation." ${ }^{198}$ NYPA may acquire such property by condemnation. ${ }^{199}$

\footnotetext{
${ }^{189}$ New York Power Authority, Who We Are, http://www.nypa.gov/about/whoweare.htm (last visited May 4, 2008).

190 New York Power Authority, Our Facilities, http://www.nypa.gov/facilities/default.htm (last visited May 4, 2008).

${ }^{191}$ Id.

192 New York Power Authority, 2004 Annual Report, Note L-Nuclear Plant Divesture and Related MatTers, (2004) available at http://www.nypa.gov/ar04/financials/index.htm.

193 New York Power Authority, Vision, http://www.nypa.gov/about/mission.htm (last visited May 4, 2008).

${ }^{194}$ N.Y. Pub. Auth. Law $\S 1001$ (McKinney 2008).

195 N.Y. Pub. Auth. Law $\S 1002$ (McKinney 2008).

${ }^{196}$ N.Y. Pub. Auth. Law $\S 1003$ (McKinney 2008).

${ }^{197}$ N.Y. Pub. Auth. Law $\S 1010$ (McKinney 2008).

${ }^{198}$ N.Y. Pub. Auth. Law $\S 1007$ (McKinney 2008).

${ }^{199}$ Id.
} 
NYPA's implementing statute provides guidance in a number of areas of particular application to NYGLOW. "[NYPA] is authorized . . . to construct . . throughout its service area ... (b) such . . . facilities utilizing new energy technologies . . . necessary (i) to supply sufficient supplemental energy to make possible optimum use of the generating capacity of [NYPA's] Saint Lawrence and Niagara hydroelectric projects . . .."200 NYPA's statutory policy declaration includes the "desirab[ility] that [NYPA] give its fullest cooperation to [NYSERDA] in advancing and promoting development and implementation of new energy technologies . . ."201 and to "enter into contractual arrangements with [NYSERDA] in connection with planning, siting, development, construction, operation, and maintenance of generating facilities of the authority utilizing new energy technologies . . "202 NYPA also has a statutory direction to "study the desirability and means of attracting industry to the state of New York." ${ }^{203}$

NYSERDA is a public benefit corporation ${ }^{204}$ with the mission to "use innovation and technology to solve some of New York's most difficult energy and environmental problems in ways that improve the State's economy." ${ }^{205}$ NYSERDA's authorizing statute provides that it has the objective of "the development and utilization of safe, dependable, renewable, and economic energy sources and the conservation of energy and energy resources." ${ }^{206}$ NYSERDA is authorized to promote these objectives through the issuance of bonds and notes for financing projects for experimental or development facilities implementing new energy technologies. ${ }^{207}$ "New energy technologies" include "all methods used to produce ... energy by methods not in common commercial use, with emphasis on renewable energy sources including but not limited to solar, wind, bioconversion and solid waste."208

NYSERDA is governed by 13 "members" including the Commissioners of the Department of Environmental Conservation and Department of Transportation, the chairs of NYPA and the Public Service Commission, and nine members appointed by the Governor with consent of the Senate. ${ }^{209}$ The Governor may veto any action taken at a meeting of the authority. ${ }^{210}$ NYSERDA is primarily funded by electricity ratepayers

\footnotetext{
${ }^{200}$ N.Y. Pub. Auth. Law $\S 1005, \pi 2$ (McKinney 2008).

${ }^{201}$ N.Y. Pub. Auth. Law $\S 1001$ (McKinney 2008).

202 N.Y. Pub. Auth. Law $\S 1005$, authority and direction, $\pi 10$.

${ }^{203}$ N.Y. Pub. Auth. Law $\S 1005$, authority and direction $\pi 4$.

${ }^{204}$ N.Y. Pub. Auth. Law $\S 1852.1$ (McKinney 2008).

${ }^{205}$ New York State Energy Research and Development Authority, Mission Statement, http://www.nyserda.org/About/about mission statement.asp (last visited May 4, 2008).

${ }^{206}$ N.Y. Pub. Auth. Law § 1850-a (McKinney 2008).

207 Id.

${ }^{208}$ N.Y. Pub. Auth. Law $\S 1851.10$ (McKinney 2008).

${ }^{209}$ N.Y. Pub. Auth. Law $\S 1852.2$ (McKinney 2008).

${ }^{210}$ N.Y. Pub. Auth. Law § 1853.1-1853.4 (McKinney 2008).
} 
through the System Benefits Charge, with a current funding level of about $\$ 175$ million per year. $^{211}$

NYSERDA's statutory purpose and powers call for it "[t]o conduct, sponsor, assist and foster programs of research, development and demonstration in new energy technologies including but not limited to . . . (b) production of power from new sources with emphasis on renewable energy sources such as solar, wind, bioconversion and solid waste, ... including the power after assessing and taking into account environmental considerations thereof, to establish, acquire, operate, develop and manage facilities therefor."212 NYSERDA's authority includes the ability to contract or enter into joint undertakings with NYPA to "[p]articipate in the construction and operation of experimental or developmental facilities which implement new energy technologies" and [d]evelop, prepare, and furnish by sale or lease real property owned, held, or acquired by the authority within the state to be used for the construction and operation of generating facilities based on new energy technologies . . . ."213 NYSERDA is authorized to acquire real property, including lands under water, which it has determined is necessary for its purposes in the name of the state by dedication, agreement, or condemnation. ${ }^{214}$

From the foregoing, it is clear the development of NYGLOW would be consistent with the mission and authority of NYSERDA and NYPA. Offshore Wind fits squarely within the definition of the "new energy technologies" for which NYSERDA is charged with fostering research, development, and demonstration programs. As these programs show the substantial potential for Offshore Wind energy production, substantial enough to "supply sufficient supplemental energy to make possible optimum use of the generating capacity of [NYPA's] Saint Lawrence and Niagara hydroelectric projects," both NYPA and NYSERDA have authority to advance and promote development and implementation of this new energy technology. Both entities also have the authority to acquire the necessary lands underwater and provide funding instruments to support the program.

Furthermore, NYPA has the statutory charge and means to attract an Offshore Wind technology and manufacturing industry to Western New York. As discussed above, NYPA has as a policy directive to "study the desirability and means of attracting industry to the state of New York." As a "market participant," NYPA would be uniquely positioned to use its status as a state authority to include local content requirements, similar to Hydro-Quebec, if it were to purchase Offshore Wind equipment directly. ${ }^{215}$

\footnotetext{
${ }^{211}$ New York State Public Service Commission, System Benefits Charge, http://www.dps.state.ny.us/sbc.htm (last visited May 4, 2008).

${ }^{212}$ N.Y. Pub. Auth. Law $\S 1854.1$ (McKinney 2008).

${ }^{213}$ N.Y. Pub. Auth. Law § 1854.3 (McKinney 2008).

${ }^{214}$ N.Y. Pub. Auth. Law $\S 1856$ (McKinney 2008).

215 See analysis of the Dormant Commerce Clause and the Market Participant exception. Shaw supra note 4 at 13-17.
} 
Furthermore, NYPA can be "market maker" by providing the long-term power purchase agreements necessary to make Offshore Wind economically attractive.

Since NYPA and NYSERDA clearly have the mission and authority to pursue Offshore Wind development in New York's Great Lakes, how should they proceed to defining a long-term strategy?

\section{The Process for Developing a Long-Term NYGLOW Strategy}

As discussed in the previous Wind Action Group background report on a process for siting Offshore Wind that gains public acceptance, and mirrored in the environmental baseline study recommended by New Jersey's Blue Ribbon Panel, the first step in a long-term strategy for developing Offshore Wind in New York's Great Lakes is to identify areas more and less suitable for Offshore Wind development using the SEQR Generic Environmental Impact Statement (GEIS) or NEPA Programmatic Environmental Impact Statement (PEIS) processes as a guide. ${ }^{216}$ To satisfy the objective of identifying areas more or less suitable for development, the GEIS or PEIS processes would likely require additional collection of data regarding such issues as avian migration routes, the presence of sensitive lake species and habitat areas, likely visual and economic impacts, effects on navigation, and effect on water quality, as well as analysis of the energy development potential, both theoretical and practical, of Offshore Wind. ${ }^{217}$ From this assessment, the prudent level of Offshore Wind development could be determined, standards for mitigating adverse environmental impacts could be developed $^{218}$ and the number of turbines which would be the basis for an RFP could be decided. (See section D.3 infra). The benefits of this approach, again as recognized in New Jersey's strategy, is to minimize the risk of adverse environmental impact on the Great Lakes ecosystem, provide a forum for public participation, and to lower the risk to developers of unforeseen delays and construction requirements. ${ }^{219}$

Initiating the GEIS process and the associated data collection and analysis is clearly within the purview of NYSERDA's authority to "assess and take into account environmental considerations" associated with new energy technologies. Because a key consideration for evaluating the prudent level of energy development is the interaction of Offshore Wind power generation and NYPA's hydropower facilities, NYSERDA and NYPA will need to partner in this assessment. As this investigation would benefit the long term Offshore Wind development program, funding through the state (as New Jersey has done), as opposed to a developer, would be appropriate, if only to ensure that the data developed is available to all potential developers. This funding could come from a number of sources, whether as part of NYSERDA's budget through the System

${ }^{216}$ Kanyuck supra note 5 at 23-27.

${ }^{217}$ Id.

${ }^{218} / d$.

${ }^{219}$ Id. 
Benefit Charge, the RGGI Allowance Account, part of NYPA's funding of new energy technologies, grants from the Federal Government ${ }^{220}$ or private foundations, or, because of the economic development potential of Offshore Wind, through an economic development grant from the Upstate Empire State Development Corporation (Upstate ESDC).

Presuming that the GEIS or PEIS processes determine that some level of Offshore Wind development is prudent and, as New Jersey has, that it will be difficult to fully predict the economic, power generation, and environmental benefits and impacts of Offshore Wind without practical experience, a pilot scale Offshore Wind project may be appropriate. $^{221}$ Part of the GEIS or PEIS processes would be to determine the size and the data collection requirements for the pilot project. This determination should take into account the minimum size necessary to assess such factors as environmental impacts, the impact to the electrical distribution system, and future financial viability and economic development potential.

Both NYPA and NYSERDA have the authority and policy directive to lead the implementation of the pilot project and should consider it a joint effort. NYSERDA's involvement would be based from the standpoint that the pilot project is substantially a development facility that will be used to assess future environmental impacts of a new energy technology. NYPA's involvement would be from the standpoint that it is the entity most likely to lead NYGLOW, through its directive to facilitate the construction of new energy technologies that optimize the use of hydropower, and that, like its hydropower and fossil fuel facilities, the pilot plant should become a NYPA asset. Additionally, NYPA's involvement in assessing the pilot plant's interaction with its existing hydropower facilities, extrapolation of energy output to determine ultimate Offshore Wind development potential, and financial viability are critical to developing the long-term NYGLOW strategy. The sources of funding for the pilot project could again come from some combination of NYSERDA, NYPA, and Upstate ESDC sources for the reasons stated above.

The GEIS or PEIS processes should provide a firm understanding of the environmental, economic, and energy generation benefits and impacts of NYGLOW. A long-term strategy could then be developed, with the participation of all community stakeholders, that would define the total prudent development potential, the locations suitable for development, the environmental mitigation measures necessary to minimize adverse impacts, and the measures needed to integrate and optimize the power generated from Offshore Wind into the regional electrical transmission system.

\footnotetext{
${ }^{220}$ For example, Toledo recently received a $\$ 250,000$ federal grant through Rep. Marcy Kaptur for wildlife studies related to offshore wind development with another $\$ 800,000$ for an offshore wind feasibility study in the Cleveland area. See Tom Henry, Wind power plan for lake gains speed; efforts totaling over $\$ 1$ million seek to win new industry, Toledo Blade (March 23, 2007) available at http://toledoblade.com/apps/pbcs.dll/article?AID=/20070323/NEWS06/703230397.

${ }^{221}$ Kanyuck supra note 5 at 27-28.
} 
The GEIS or PEIS could then further be refined to provide for defined requirements for individual project environmental reviews, thereby streamlining the individual project process, establishing measures to meet permitting requirements of federal agencies, ${ }^{222}$ and providing the foundation for satisfaction of the public trust doctrine. ${ }^{223}$ The cost impact on ratepayers could be understood and the economic development potential determined. How then would this long-term strategy be implemented in a way that spurs economic development?

\section{Implementing NYGLOW}

NYPA is the key entity to facilitate implementation of NYGLOW under the guise of developing new energy technologies that supply supplemental energy to optimize NYPA's hydroelectric capacity. NYPA has the existing ability to issue bonds to finance the projects, acquire the necessary real estate, including lands underwater, operate, or contract to operate, the facilities, and integrate the generated power with its hydropower resources into the regional electrical transmission system. As mentioned above, NYPA also has the ability as a "market participant," to use its status as a state authority to include local content requirements, similar to Hydro-Quebec, in Offshore Wind contracts.

NYPA could be the entity that develops and/or owns the offshore wind turbines, thus insulating the local content requirement from concerns under the dormant Commerce Clause. ${ }^{224}$ A number of arrangements are possible. One is that NYPA becomes the exclusive developer of any wind projects in New York's Great Lakes. This would be a public ownership model where NYPA would own and operate the offshore wind facilities in the same way as it does its hydroelectric plants. It could then issue a RFP for the purchase of a set number of turbines, perhaps 1,000 over a four-year period, and require that the turbines have a local content (made in upstate New York) of a specific percentage of the overall cost ( $60 \%$ possibly). A variation on this arrangement would have NYPA outsource the construction and/or operation of the facilities to private entities, but still purchase and own the turbines itself and sell the power.

\footnotetext{
222 Id. at 23-24.

${ }^{223}$ Id. at 9-12.

${ }^{224}$ New York State can choose to make NYPA, a political subdivision of the state, the exclusive developer of its offshore wind resource without violating the dormant Commerce Clause. See United Haulers Association v. Oneida-Herkimer Solid Waste Management Authority, 127 S. Ct. 1786 (2007). Then NYPA can exercise its right to participate in the market and choose to purchase turbines that meet its criteria for local content. This would meet the "market participant" exception and would thus insulate its preference for New York products from attack under the dormant Commerce Clause. (See Shaw supra note 4 at 1516). NYPA would be purchasing these turbines itself, rather than requiring a developer to do so, thereby eliminating concerns that it is trying to regulate the separate economic relationships of private companies.
} 
Either of these variations presents both positive and negative aspects. Public acceptance of offshore wind turbines might be enhanced if there were a sense that all the benefits of using the publicly owned lake beds and wind resource were going to a public entity rather than to the profits of a private company. This might be even more likely if NYPA were to use some or all of its proceeds from selling this power to enhance the local communities near the lakes as well as possibly devoting some to the restoration of the lakes themselves. A significant problem with this public ownership model is that NYPA could not take advantage of the federal Production Tax Credit even if it is extended. The only federal incentive programs that NYPA could use are the REPI and CREBs programs, but as previously discussed these programs have either not been sufficiently funded for a number of years or have not been renewed. Perhaps the federal law could be amended to encourage offshore wind development by renewing CREBs and giving these facilities priority under REPI (or even an enhanced payment), and ensuring sufficient appropriations. This would be a sensible policy to encourage the development of this newer technology and follow the lead of a number of European countries as discussed in Section C.3 supra.

Another model for NYPA to follow would be for NYPA to purchase the wind turbines using the local content requirement, but then allow private companies to actually develop, own and operate the projects. NYPA would offer long term power purchase contracts and part of the proposal would be the use of the turbines that NYPA had arranged to purchase. This could be accomplished through a sale of the turbines to the developer or some other arrangement which would be sufficient to allow the developer to claim the federal Production Tax Credit. As has been done by HydroQuebec, NYPA could bid large lots of the prudent Offshore Wind capacity, determined in the long-term strategy, to create a large Offshore Wind market. 


\section{Policy Recommendations}

NYPA and NYSERDA currently possess the statutory authority to create and implement a long-term Offshore Wind development strategy for New York's Great Lakes. The basis for a policy recommendation then is to include NYGLOW as part of NYPA's and NYSERDA's agenda.

The recommended path for creating a long-term NYGLOW strategy starts as a rollout of the GEIS or PEIS processes by NYSERDA, with NYPA's support and the collaboration of the Army Corps of Engineers, followed by accompanying environmental and energy studies and, possibly, a pilot facility. In many ways, this beginning step is the equivalent of the formation of New Jersey's Blue Ribbon Panel initiated by the Governor of New Jersey. Similarly, the Governor of New York could provide direction to NYSERDA and NYPA through the Governor's Task Force to include the aforementioned Offshore Wind GEIS or PEIS as part of its project plans and budgets. Alternatively, NYSERDA could include the GEIS or PEIS program as part of its renewable energy development program. ${ }^{225}$ Further policy impetus and funding can come from the Upstate ESDC as part of a long-term Western New York economic development strategy.

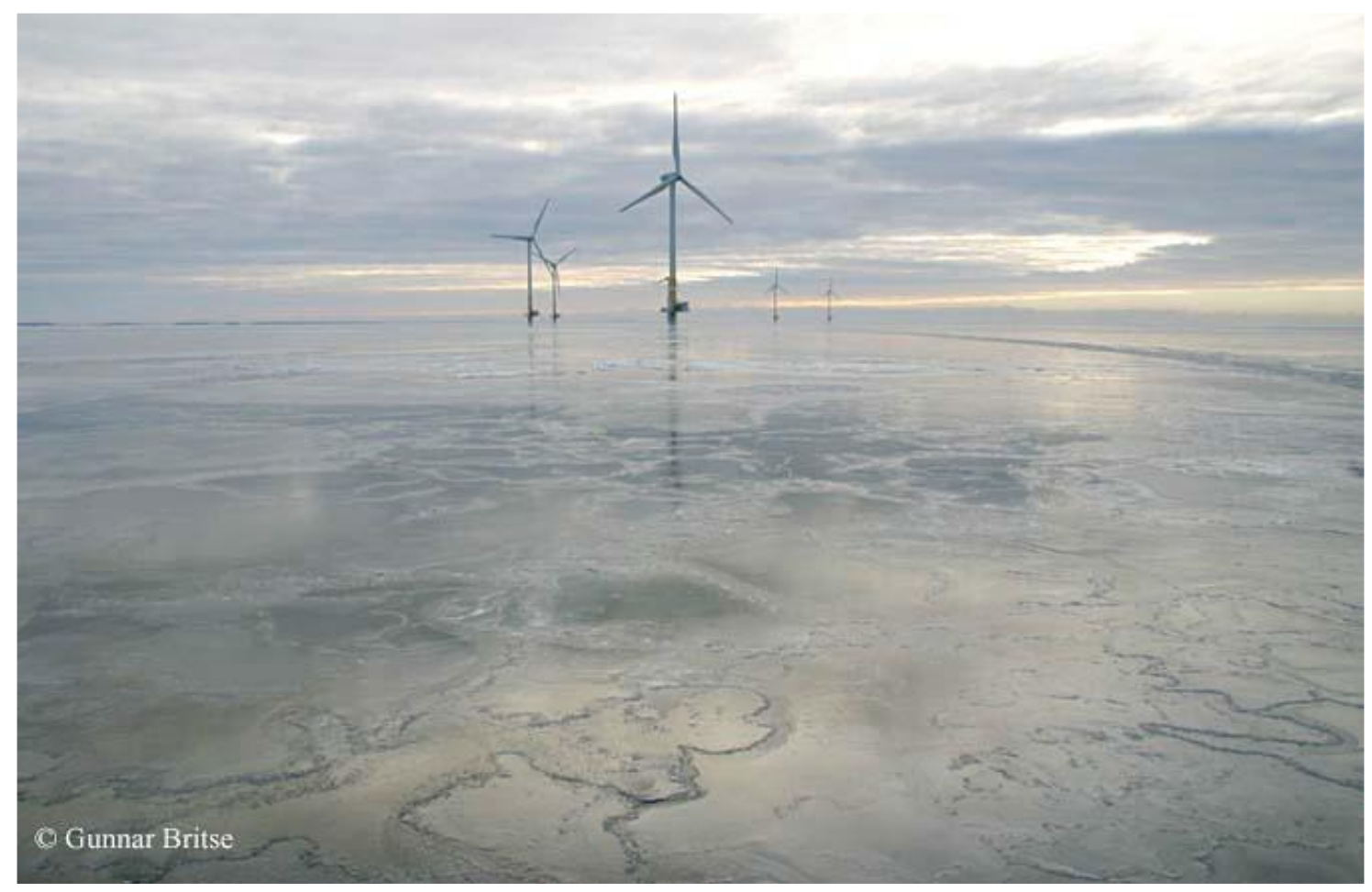

Ice-Winter in Kalmarsund, Sweden

\footnotetext{
${ }^{225}$ New York State Energy Research and Development Authority, Power Naturally, http://www.powernaturally.org/ (last visited May 4, 2008).
} 
While NYPA and NYSERDA have the existing authority to begin the GEIS process for Offshore Wind, a more effective long-term strategy may be to consider legislation to explicitly integrate NYGLOW into NYPA's statutory mission. Although a legislative approach may be more challenging in the short term, it would provide an indication of broader public support and would ensure that Offshore Wind is a priority with NYPA. Legislation may also be more effective at ensuring that other state governmental Offshore Wind stakeholders, such as the DEC Climate Change Office and the Division of Coastal Resources, are appropriately engaged in the process. Legislation would also provide recognition that the time is now to develop a long term NYGLOW strategy if it is to result in substantial economic development benefits before other states, such as Ohio, gain a foothold in component manufacturing.

The Wind Action Group can help to bring the potential for Offshore Wind in New York's Great Lakes to fruition by engaging all elements of the community in a discussion of this topic. This includes environmental groups, labor unions, businesses and concerned citizens. WAG also can help organize an advocacy campaign to implement NYGLOW addressed to the Governor, NYSERDA, NYPA, state and local legislators, and local IDA and ESDC representatives, encouraging their support for the necessary resources and oversight to initiate the program. 


\section{Resource List}

David Bradley, A Great Potential: The Great Lakes as a Regional Renewable Energy Source (February 6, 2004), http://greengold.org/wind/documents/107.pdf.

Ian A. Bowles, Certificate of the Secretary of EnVironmental Affairs on the Final Project Impact Report, CAPe Wind Project, The Commonwealth of Massachusetts ExeCutive Office of ENVIRONMENTAL AfFAIRS (March 29, 2007) available at http://www.mass.gov/envir/mepa/pdffiles/certificates/032907/12643feir.pdf.

Elinor Burkett, A Mighty Wind, New York Times Magazine, June 15, 2003, at 48 available at http://query.nytimes.com/gst/fullpage.html?res=9804E6DE1239F936A25755C0A9659C8B63.

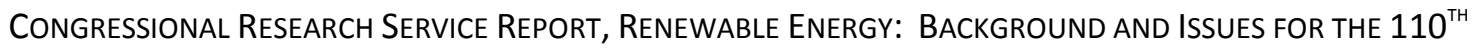
CONGRESS (Dec. 2007).

Cuyahoga County Regional Energy Task Force, Building a New Energy Future, Recommendations for a LaKe ERIE OfFSHORE Wind Energy Demonstration Project ANd ReSEARCh Center (February 8, 2007) available at http://www.cuyahogacounty.us/pdf/RegEnergyTF.pdf.

Jennifer Delony, Windbearings, North American Windpower, March 2008

Energy Information Administration, Existing Electric Generating Units in the United States, 2005 (April 17, 2008) available at http://www.eia.doe.gov/cneaf/electricity/epa/epat2p2.html

Environment Canada, Canadian Wildlife Service, Wind Turbines and Birds, A Guidance Document FOR ENVIRONMENTAL ASSESSMENT (February 2007) available at https://www.extranet.mnr.gov.on.ca/renewable/windpowernew/Environmental\%20Approvals.html (registration and password required).

Federal Ministry for EnVironment, Nature Conservation, and Nuclear Safety (Germany), ReNEWABLE ENERgy SOURCES ACT; Progress RePORT 2007 (Dec. 12, 2007) available at http://www.bmu.de/english/renewable energy/downloads/doc/40943.php.

Paul Gipe, Renewable Energy Policy MeChanisms (February 17, 2006) available at http://www.wind-works.org/FeedLaws/RenewableEnergyPolicyMechanismsbyPaulGipe.pdf.

DWight Kanyuck, Wind Action Group, Promoting Offshore Wind Energy in NeW York's Great Lakes (May 2007), http://greengold.org/wind/legal.php.

KPMG, OFFSHORE WIND FARMS IN EUROPE(2007) available at http://www.kpmg.com.au/Portals/0/KPMG Offshore wind farms in Europe 2007.pdf

State of New Jersey Blue Ribbon Panel on DeVelopment of Wind Turbine Facilities in CoAstal WATERS, FINAL REPORT TO GOVERnOR JON S. CORZINE (April 2006) available at http://www.state.nj.us/njwindpanel/. 
Minerals Management Service, Cape Wind Energy Project, Draft Environmental Impact Statement (August 2004) available at

http://www.mms.gov/offshore/AlternativeEnergy/CapeWindDEIS.htm.

New Jersey Board of Public Utilities, Solicitation for Proposals to Develop Off-Shore Wind Renewable Energy Facilities Supplying Electricity to the Distribution System Serving New Jersey (October 5, 2007) available at http://www.njcleanenergy.com/files/file/OSWFinalSolicitation100507final.pdf.

New Jersey Department of Environmental Protection, Division of Science, Research, and Technology Solicitation for Research Proposals, Ocean/Wind Power Ecological Baseline Studies (April 19, 2007) available at http://www.nj.gov/dep/dsr/ocean-wind/srp-wind-ocean.pdf.

New York Lieutenant Governor's Renewable Energy Task Force, Clean, Secure Energy and ECONOMic GRoWth: A COMmitMENT to ReNEWABLE ENERGY AND INCREASED ENERGy INDEPENDENCE, The Challenge (February 2008) available at http://www.ny.gov/governor/press/It RETF Report.pdf.

Natural Resources Canada, ecoEnergy for Renewable Power (April 2007) available at http://www.ecoaction.gc.ca/ecoenergy-ecoenergie/power-electricite/conditions-eng.pdf.

New York Power Authority, 2004 Annual Report, Note L-Nuclear Plant Divesture and Related MATTERS (2004) available at http://www.nypa.gov/ar04/financials/index.htm.

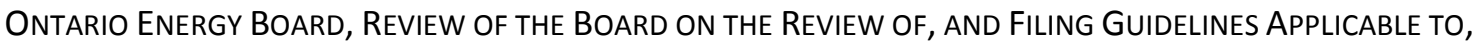
the ONtario PoWer Authority's Integrated PoWer System Plan and Procurement Process (December 27, 2006) available at http://www.powerauthority.on.ca/ipsp/Storage/48/4389 A3-1.pdf.

Ontario Ministry of Natural Resources, Application ReVIeW and Land Disposition Process, Policy PL 4.02.01 (June 7, 2005) available at http://publicdocs.mnr.gov.on.ca/View.asp?Document ID=2294\&Attachment ID=7533.

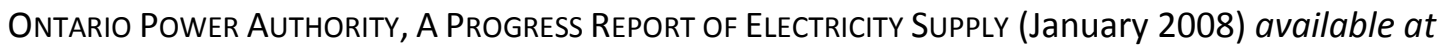
http://www.powerauthority.on.ca/Storage/65/6055 Progress Report on Electricity Supply January 2008.pdf. Report discusses individual contracts, Ontario's Standard Offer Program, and contains detailed status of projects under construction.

ONTARIO POWER AUthority, IPSP PROCUREMENT PROCESS, EB-2007-0707 (2007) available at http://www.powerauthority.on.ca/ipsp/Page.asp?PagelD=122\&ContentID=6184\&SiteNodelD $=3$ 20\&BL ExpandID $=$.

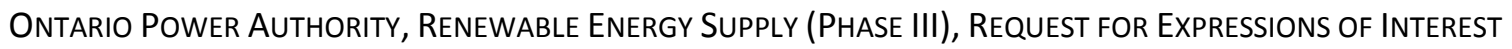
(November 20, 2007), available at http://www.powerauthority.on.ca/GP/Page.asp?PagelD=122\&ContentID=696\&SiteNodeID=180 $\underline{\text { \&L ExpandID }}=$. 
Ontario Power Authority, The Integrated Power System Plan for the Period 2008-2027 (October http://www.powerauthority.on.ca/ipsp/Page.asp?PagelD=122\&ContentID=6184\&SiteNodelD=3 20\&BL ExpandID $=$.

Pace Global Energy Services, Assessment of Offshore Wind Power Resources, Long Island Power AUTHORITY (August 22, 2007) available at http://www.lipower.org/newscenter/pr/2007/pace wind.pdf.

Regional Greenhouse Gas Initiative, Memorandum of Understanding (December 20, 2005) available at http://www.rggi.org/docs/mou final 1220 05.pdf.

Ressources naturelles at Faune Quebec, Energy for Prosperity in Quebec, Objectives and ORIENTATIONS OF THE ENERGY STRATEGY (November 2005) available at http://www.mrnf.gouv.qc.ca/english/publications/energy/strategy/guidelines-strategy.pdf.

Riso National Laboratory, SUStaINABLE ENERgy IRELAND, OfFSHORE WIND ENERGY AND INDUSTRIAL DEVELOPMENT IN THE REPUBLIC OF IRELAND (October 2004) available at www.sei.ie/getFile.asp?FC ID=1721\&docID=65.

Robert SHAW, Wind ACtion Group, OfFSHORE WIND'S Role IN DEVELOPING A WIND ENERGY INDUSTRY IN WESTERN NEW YORK (May 2007), http://greengold.org/wind/legal.php.

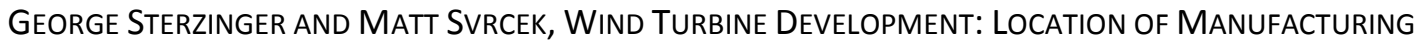
Activity, Renewable Energy Policy Project (September 2004) available at http://www.repp.org/articles/static/1/binaries/WindLocator.pdf.

U.S. Department of Energy, Energy EfFiciency And Renewable Energy, FisCAL YeAR 2009 Budget-INBRIEF (2008) available at http://www1.eere.energy.gov/ba/pba/pdfs/FY09 budget brief.pdf.

Channel White, Wind Action Group, Ontario's Development of Offshore Wind in the Great Lakes (June 2007) http://www.greengold.org/wind/legal.php.

Wendy Williams and Robert Whitcomb, Cape Wind (2007) 
Report prepared by

\section{Environment and Development Clinic}

University at Buffalo Law School

The State University of New York

507 O'Brian Hall

Buffalo, NY 14260-1100

T: 716.645 .2167

F: 716.645.2064

W: www.law.buffalo.edu/Clinics

Report prepared for

Wind Action Group

E: windmail@GREENGOLD.org

W: www.greengold.org/wind/ 